\title{
A 10 kW ZVS Integrated Boost Dual Three-Phase Bridge DC-DC Resonant Converter for a Linear Generator-Based Wave-Energy System: Design and Simulation
}

\author{
Nagendrappa Harischandrappa ${ }^{1, *}$ and Ashoka K. S. Bhat ${ }^{2}$ \\ 1 National Institute of Technology Karnataka, Surathkal, Mangalore 575025, India \\ 2 University of Victoria, Victoria, BC V8W 2Y2, Canada; bhat@ece.uvic.ca \\ * Correspondence: nagendrappa@gmail.com; Tel.: +91-824-247-3452
}

Received: 14 January 2019; Accepted: 16 January 2019; Published: 21 January 2019

check for updates

\begin{abstract}
The design and performance analysis of a $10 \mathrm{~kW}$ three-phase DC-DC LCL-type resonant converter having a built-in boost function were carried out. This high-power converter is proposed for its application in grid-interfacing a linear generator (LG)-based wave-energy system. Fixed-frequency control is used, and the converter was designed to operate with a lagging power factor. It is shown that all switches turn on with zero-voltage switching (ZVS) for wide input voltage and load variations. This results in reduced switching losses and stresses, which is very important in large-power applications. The performance of the converter was studied through PSIM simulation software. Theoretical and simulation results are presented for comparison. Power-loss break-down analysis of the designed converter was carried out and the summary of results is presented.
\end{abstract}

Keywords: LCL-resonant converter; DC-DC; integrated boost; dual three-phase bridge; fixed frequency; ZVS; large power

\section{Introduction}

Large renewable power plants are supplementing conventional power generation to face the looming energy crisis. Power from ocean waves is a huge source of renewable power that remains mostly untapped [1-4]. Wave-energy converters (WEC) are required to convert the motion of waves into electricity. Technology is slowly advancing to determine a robust WEC device [5-7]. The following wave-energy conversion technologies are reported in the literature: (i) attenuator, (ii) oscillating water column, (iii) overtopping, and (iv) point absorber. Among these technologies, one of the point-absorber type of devices, called Archimedes wave swing (AWS), is currently the most attractive device [8-10]. AWS uses a direct-drive linear generator (LG) to convert its reciprocating motion into electricity [11-15]. The structure and typical waveform of the output voltage of an LG is shown in Figure 1. This electricity cannot be used since it is a variable low frequency, wide-varying low voltage, and non-sinusoidal AC power. Hence, a suitable power electronic interface is essential to make this power usable and facilitate grid interfacing of the wave-energy source [16-18]. For grid interfacing, the variable-voltage and variable-frequency output power from LG has to be conditioned to match the grid characteristics. In grid interfacing, the LG output is first converted into DC using a front-end diode rectifier. A two stage DC-DC converter is used to change the magnitude of input DC voltage and provide galvanic isolation using a High-Frequency (HF) transformer. In the DC-DC converter, the input DC is first converted into an HF AC using an HF-switched inverter. This AC is fed to the primary of the HF transformer to change its voltage level, in addition to providing isolation. The secondary-side voltage is converted back into the DC using an output rectifier. This DC is finally converted into the 
line-frequency $\mathrm{AC}$ of magnitude equal to the grid voltage. The block diagram of grid integration of a wave-energy plant is shown in Figure 2. The power rating of linear generators used in wave-energy generation is typically of the order of tens to hundreds of $\mathrm{kWs}$ [2-4]. To realize DC systems in such high-power applications, DC-DC converters are very important, especially when HF transformer isolation and different voltage levels are required [19]. Different types of direct-drive power takeoff systems used in harnessing wave energy using linear generators are described in References [20-23].

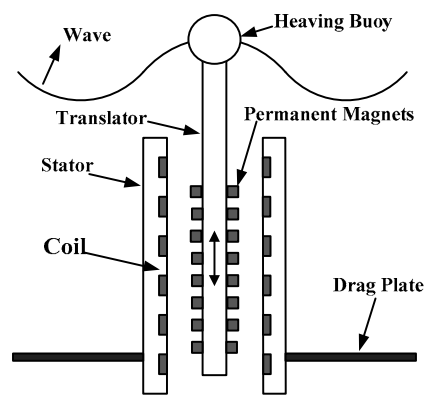

(a)

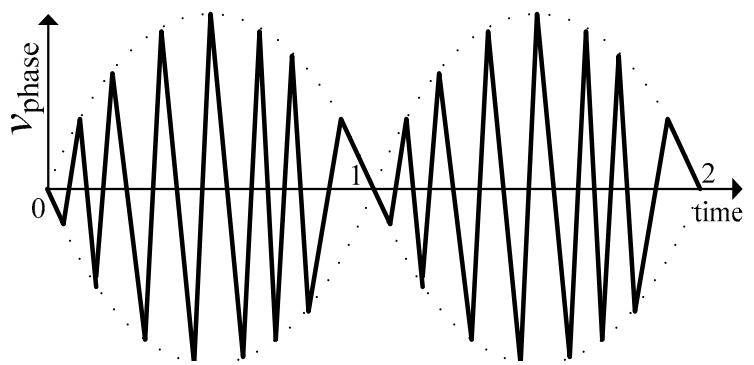

(b)

Figure 1. (a) Structure of a permanent-magnet linear generator, (b) typical waveform of phase voltage of a linear-generator output $\left(v_{\text {phase }}\right)$.

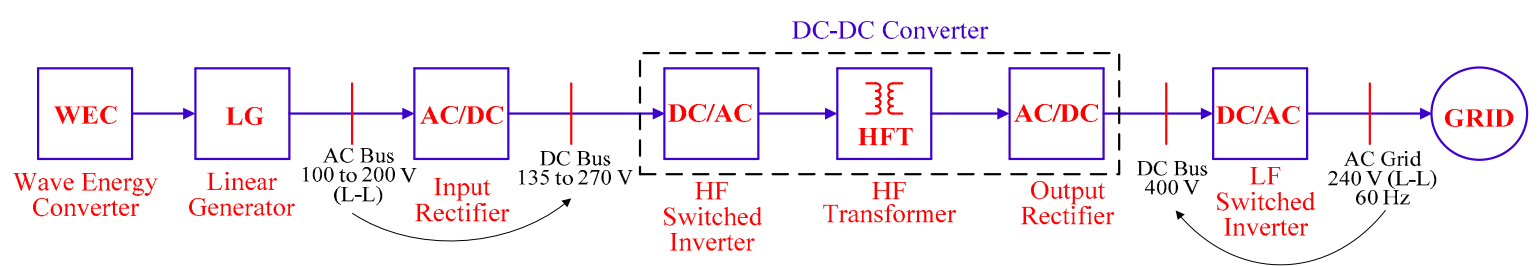

Figure 2. Block diagram of grid integration of a wave-energy plant [24].

DC-DC converters used for this type of application (true with most alternate-energy sources) have to operate with a very wide change (e.g., 2:1) in input voltage while requiring output-voltage step-up (boost) characteristics. With the HF transformer isolation and soft-switching, the efficiency of the DC-DC converters can be increased in addition to reducing the size and cost of the power-conditioning unit with overall improved performance. Therefore, DC-DC resonant converters are proposed for this application. Some converter topologies available in the literature for large-power generation applications are: A $10 \mathrm{~kW}$ dual three-phase bridge DC-DC converter was designed, and its simulation results are given in Reference [24]. Design, analysis, and experimental results of a $600 \mathrm{~W}$ dual-bridge DC-DC converter are presented in Reference [25], and it is proposed for still higher power ratings. In Reference [26], a comparison of $100 \mathrm{~kW}$ DC-DC soft-switching converter topologies is presented. In Reference [27], the performance of a high power-density $50 \mathrm{~kW}$ DC-DC converter with single-phase dual-active bridge topology is presented. The performance of an LCL-type DC-DC series resonant-converter topology with experimental results of a $300 \mathrm{~W}$ prototype is presented in Reference [28]. A $1 \mathrm{~kW}$ series-parallel DC-DC resonant converter with an input-boosting feature is described and the experimental results are presented in Reference [29]. The detailed design procedure of a dual half-bridge LCL-type series resonant converter with integrated boost function is given and simulation results of a $2.4 \mathrm{~kW}$ rating converter are presented in Reference [30]. Steady-state analysis of a ZVS PWM converter and its small-signal analysis is described, and the experimental results of a $2 \mathrm{~kW}$ prototype are presented in Reference [31]. The experimental results of a $1 \mathrm{MW}$ dual-active bridge DC-DC converter are presented, and its performance and control are validated in Reference [32]. The design and PSIM simulation study of the performance of a $10 \mathrm{~kW}$ three-phase DC-DC LCL-type series resonant converter with integrated boost function are presented in Reference [33] for steady-state operating conditions. In Reference [34], it is shown that conduction loss and switching losses are reduced for an isolated bidirectional dual-active-bridge series-resonant DC-DC converter operating at 
high frequency. The results are validated with a $1 \mathrm{~kW}$ prototype of the converter. An isolated high-gain DC-DC converter for PV applications is proposed, and its performance is studied through simulations and also by building a prototype of $3 \mathrm{~kW}$ power rating in Reference [35]. The steady-state analysis and performance study of a three-phase DC-DC converter, and the simulation and experimental results of a $900 \mathrm{~W}$ converter prototype, are presented in Reference [36]. The converter topology proposed in References $[24,25]$ has several advantages over the other topologies. Some of these advantages are reduced stress on components and filter size with fixed-frequency operation, a wide ZVS range for wide variations in input voltage, and at least $50 \%$ of load can be supplied in the case of a fault on one of the modules. Hence, this topology has been chosen to design the converter for medium-to-large power-generation applications. The work presented in this paper is an extension of the author's $\mathrm{PhD}$ thesis [24]. A performance study of the designed converter under step changes in load through PSIM simulations is the major contribution. The outline of this paper is as follows: In Section 2, the circuit details of the designed converter are briefly presented. In Section 3, the design summary of the converter, including the selection of voltage and power rating, is presented. In Section 4, the performance of the converter for variations in input voltage and load under a steady state and for step changes in the load is studied through PSIM simulations, and the results are presented. Conclusions are drawn in Section 5.

\section{Circuit Details of the Designed Converter}

The circuit diagram of the converter designed in this paper for large-power applications as proposed in References [24,25] is shown in Figure 3. This converter consists of two three-phase inverter bridges, each having six metal-oxide-semiconductor-field-effect-transistors (MOSFETs) with antiparallel diodes and a lossless snubber capacitor across it. The output terminals of these inverters are connected to a three-phase diode rectifier through a three-phase resonant circuit consisting of inductance $L_{\mathrm{s}}$ and capacitance $C_{\mathrm{s}}$ in each phase and a three-phase HF transformer $\left(T_{1}, T_{2}\right)$ of $1: n_{\mathrm{t}}$ turns ratio. These modules are supplied with $V_{\text {bus }}$ and are connected in parallel so that they equally share the load power. Between the same output phases of the two inverter bridges, the primary windings of a three-phase HF-boost transformer $\left(T_{3}\right)$ of $n_{\mathrm{b}}: 1$ turns ratio are connected. The output of the boost transformer is given to a three-phase diode boost-rectifier bridge. The boost-rectifier bridge output voltage is filtered by $L_{\mathrm{f}}$ and $C_{\mathrm{f}}$. This filtered output voltage $\left(V_{\text {boost }}\right)$ is connected in series with the input DC source to realize power supply $V_{\text {bus }}$ (i.e., $\left.V_{\text {bus }}=V_{\text {in }}+V_{\text {boost }}\right)$, applied across three-phase inverter bridge Modules 1 and 2. The secondary windings of the three-phase boost transformer are shown in Wye connection (they can also be connected in $\Delta$ ). The gating signals for the three-phase inverter-bridge switches are $180^{\circ}$ wide [24,25]. Six gating signals are required for each three-phase bridge, and these gating signals are applied in order, with a delay of $60^{\circ}$ to obtain balanced three-phase inverter output voltage. Each switch conducts for $180^{\circ}$, and three switches remain on at any point of time in a given interval (e.g., $S_{1} S_{2} S_{3}, S_{2} S_{3} S_{4}, S_{3} S_{4} S_{5}, S_{4} S_{5} S_{6}, S_{5} S_{6} S_{1}, S_{6} S_{1} S_{2}$ ). There are six intervals of operation in each cycle, and the duration of each interval is $60^{\circ}$. Fixed-frequency control is obtained by phase shifting the gating signals of Module 2 with respect to Module 1 by an angle $\delta$, which creates potential difference across the primary windings of the HF-boost transformer. At minimum input voltage $\left(V_{\mathrm{in}, \mathrm{min}}\right)$ and full load, the gating signals of Module 2 are shifted by $180^{\circ}$ to generate a square-wave voltage waveform of pulse width, $\delta=\pi$ in each phase across the primary windings of the three-phase boost transformer. The phase shift is varied to change the pulse-width $d$ of quasisquare wave generated across the primary windings of boost transformer $T_{3}$ to regulate the load voltage for variations in input voltage and load. 


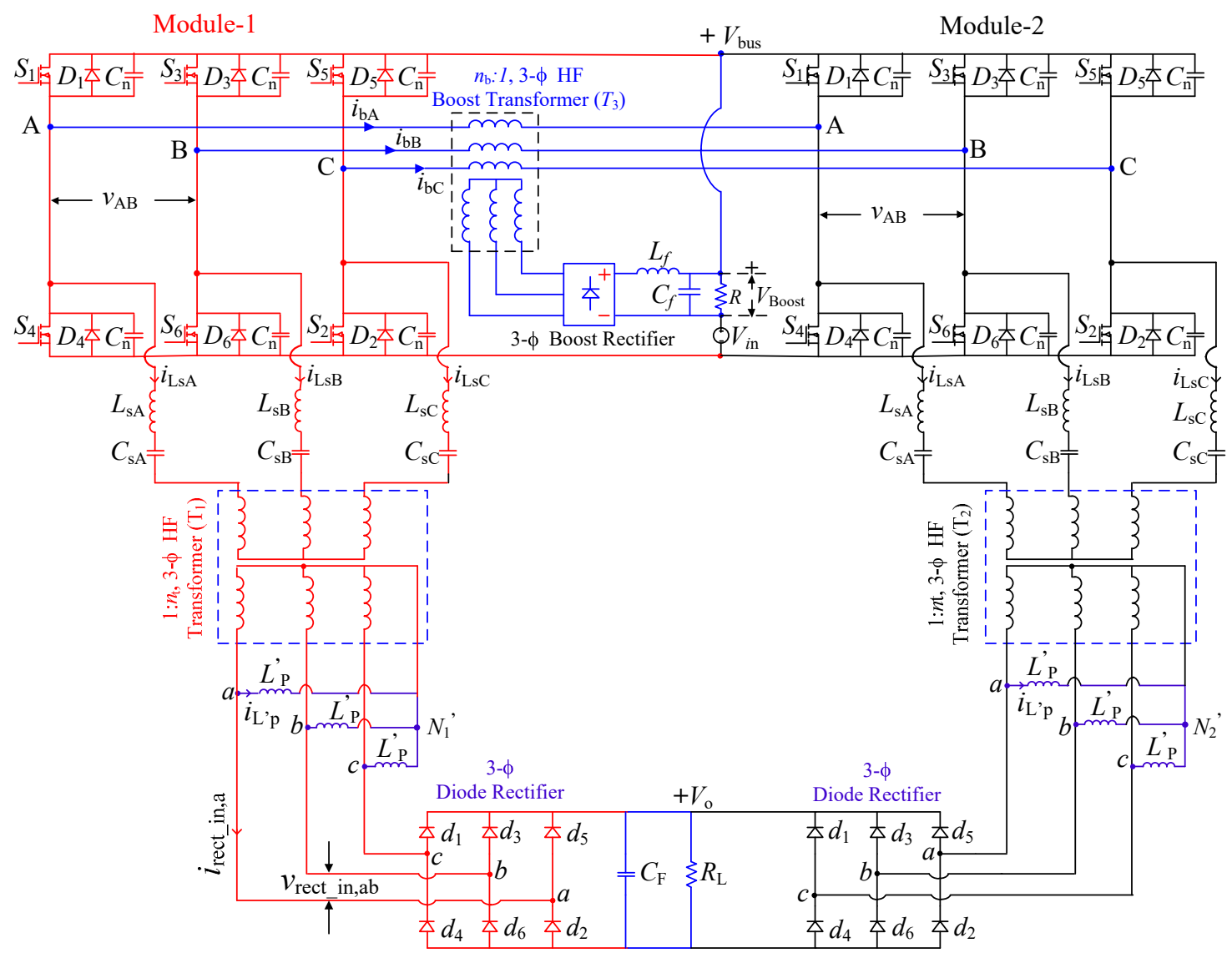

Figure 3. Proposed DC-DC LCL-type series resonant converter [24,25].

\section{Design}

The analysis presented in References $[25,28]$ was used in designing the converter. The design procedure, as given in References [24,28], was followed in designing the fixed-frequency controlled ZVS-integrated boost dual three-phase bridge DC-DC LCL-type series resonant converter for linear generator-based large-wave-power generation applications. In this section, the selection of voltage and power ratings is first discussed, and then design summary is presented.

\subsection{Selection of Voltage and Power Ratings}

A number of LGs used in wave power with different specifications are found in the literature [1-11]. The power and input voltage ratings are chosen as per the LG ratings given in References [2,33]. In Table 1, the specimen specifications of an LG, as given in Reference [2], are presented. For illustration purposes, a grid voltage of $240 \mathrm{~V}(\mathrm{~L}-\mathrm{L})$ and $60 \mathrm{~Hz}$ is considered. Based on this grid voltage, the output-voltage rating of the designed converter was obtained as $400 \mathrm{~V}$. The criterion for choosing $V_{\text {bus }}$ is $V_{\text {bus }}(\min )>V_{\text {in }}(\max )$, and $V_{\text {bus }}(\max )$ is decided based on the available higher voltage ratings of the switching devices. This idea of a design with a higher $V_{\text {bus }}$ value reduces the switch currents and voltage ratings of the HF transformer, and the tank circuit elements. Based on this criterion, $V_{\text {bus }}=600 \mathrm{~V}$ was chosen [25]. This DC bus voltage was applied across the three-phase HF inverter bridges. 
Table 1. Linear-generator specifications $[2,33]$.

\begin{tabular}{ll}
\hline \multicolumn{1}{c}{ Parameter } & Value \\
\hline Rated power at $0.7 \mathrm{~m} / \mathrm{s}$ & $10 \mathrm{~kW}$ \\
Open circuit voltage (Line) at $0.7 \mathrm{~m} / \mathrm{s}$ & $200 \mathrm{~V}$ \\
Generator resistance & $0.44 \Omega$ \\
Generator inductance & $11.7 \mathrm{mH}$ \\
Iron losses at $0.7 \mathrm{~m} / \mathrm{s}$ & $0.57 \mathrm{~kW}$ \\
Length of air gap & $3 \mathrm{~mm}$ \\
Size of magnet block & $6.5 \times 35 \times 100 \mathrm{~mm}^{3}$ \\
Pole width & $50 \mathrm{~mm}$ \\
Stator sides (number) & 4 \\
Stator length (vertical) & $1.264 \mathrm{~m}$ \\
Translator length (vertical) & $1.867 \mathrm{~m}$ \\
Weight of translator & $1000 \mathrm{~kg}$ \\
\hline
\end{tabular}

\subsection{Design Summary}

The converter was designed by following the procedure outlined in References [24,28], and the key design equations, together with various parameter notations, are summarized in Appendix A. The specifications of the designed converter are given in Table 2. Using the design curves presented in Reference [25], the design parameters are optimized. The selected parameters are $\mathrm{Q}=4, \mathrm{~F}=1.1$, and $\mathrm{L}_{\mathrm{s}} / \mathrm{L}_{\mathrm{p}}=0.1$. For the chosen design parameters, converter gain $\mathrm{M}\left(=V^{\prime}{ }_{\mathrm{o}} / V_{\text {bus }}\right)$ was calculated by using Equation (A15) as $\mathrm{M}=0.6286$ p.u. Output voltage, when reflected on primary side of the $\mathrm{HF}$ transformer, is $\mathrm{V}^{\prime}{ }_{\mathrm{o}}=\mathrm{V}_{\mathrm{o}} / \mathrm{n}_{\mathrm{t}}=371.2 \mathrm{~V}$. Therefore, the HF main transformer $\left(\mathrm{T}_{1}\right.$ and $\left.\mathrm{T}_{2}\right)$ turns the ratio of $n_{t}=V_{o} / V^{\prime}{ }_{o}=1.078$. Load resistance $R_{L}=V_{o}{ }^{2} /\left(P_{o} / 2\right)=32 \Omega$ (since each module equally shares the load, power output is taken as $P_{o} / 2=5 \mathrm{~kW}$ ). The load resistance referred to on the primary side, $\mathrm{R}_{\mathrm{L}}{ }^{\prime}=\mathrm{R}_{\mathrm{L}} / \mathrm{n}_{\mathrm{t}}{ }^{2}=27.54 \Omega$. The values of tank circuit elements $\mathrm{L}_{\mathrm{s}}$ and $\mathrm{C}_{\mathrm{s}}$ are determined by solving Equation (A16) as, $\mathrm{L}_{\mathrm{s}}=192.97 \mu \mathrm{H}$ and $\mathrm{C}_{\mathrm{s}}=15.88 \mathrm{nF}$. Since $\mathrm{L}_{\mathrm{s}} / \mathrm{L}_{\mathrm{p}}=0.1, \mathrm{~L}_{\mathrm{p}}=1.93 \mathrm{mH}$ on the primary side. Therefore, $\mathrm{L}_{\mathrm{p}}^{\prime}=\mathrm{n}_{\mathrm{t}}^{2} \mathrm{~L}_{\mathrm{p}}=2.24 \mathrm{mH}$ is connected on the secondary side in each phase. This includes the magnetizing inductance of the HF transformer. Total impedance using Equations (A17)-(A22) is $Z_{\mathrm{AN}}=16.75+\mathrm{j} 21.27 \Omega,\left|Z_{\mathrm{AN}}\right|=27.08 \Omega, \varphi=51.78^{\circ}$. The maximum current in the tank circuit elements $L_{\mathrm{S}}$ and $C_{\mathrm{S}}$ using Equation (A23) is $I_{\mathrm{Lsp}}=14.11 \mathrm{~A}$. The maximum value of voltage across $C_{s}$ using Equation (A25), $V_{\mathrm{Csp}}=1.41 \mathrm{kV}$. The maximum value of the current through STAR-connected parallel inductors $L_{p}^{\prime}$ on the secondary side is $I_{L^{\prime} p, p}=163 \mathrm{~mA}$. If the parallel inductors are connected in $\Delta$, then the peak value of current through the $\Delta$-connected inductors $L_{\mathrm{ab}}, L_{\mathrm{bc}}, L_{\mathrm{ca}}$ (secondary side) is $I_{\mathrm{Lab}, \mathrm{p}}=94.11 \mathrm{~mA}$. The initial tank current using Equation (A24) is $I_{\mathrm{Ls} 0}=-11.09 \mathrm{~A}$. The negative sign of $I_{\mathrm{Ls} 0}$ indicates that the tank circuit is operating in lagging pf mode. The per-phase inductance required in the primary windings of the three-phase boost transformer calculated using Equation (A14) is $2.75 \mu \mathrm{H}$. The $L_{\mathrm{f}}$ and $C_{\mathrm{f}}$ filter components of the three-phase boost rectifier, determined using Equations (A12)-(A13), are $L_{\mathrm{f}}=5.0 \mu \mathrm{H}$ and $C_{\mathrm{f}}=20.0 \mu \mathrm{F}$. The device ratings, calculated using Equations (A1)-(A10), are: MOSFET: $I_{\mathrm{sw}}(\mathrm{rms})=22.91 \mathrm{~A}, I_{\mathrm{sw}}(\mathrm{av})=13.17 \mathrm{~A}, V_{\mathrm{DS}}(\max )=600 \mathrm{~V}$ and, $I_{\mathrm{DM}}(\mathrm{av})=0.84 \mathrm{~A}$. Boost rectifier diodes: $I_{\mathrm{Db}}(\mathrm{av})=24.69 \mathrm{~A}, V_{\mathrm{Db}}(\max )=465 \mathrm{~V}$. Output rectifier diodes: $I_{\mathrm{Do}}(\mathrm{av})=4.17 \mathrm{~A}, V_{\mathrm{Do}}(\max )=400 \mathrm{~V}$. For the chosen value of $V_{\text {bus }}=600 \mathrm{~V}, \mathrm{IXYS}-\mathrm{VMM} 90-09 \mathrm{~F}(900 \mathrm{~V}$, $\left.85 \mathrm{~A}, R_{\mathrm{DS}}=76 \mathrm{~m} \Omega, t_{\mathrm{f}}=140 \mathrm{~ns}\right)$ MOSFET was selected so that $\mathrm{HF}$ operation was possible and converter specifications were met. A snubber capacitance of $C_{n}=4.64 \mathrm{nF}$ was found for the chosen MOSFET, with a switch turn-off current $i_{0}=39.78 \mathrm{~A}$ using Equation (A11). A series/parallel combination of selected MOSFETs or insulated-gate-bipolar-transistors (IGBTs) would further increase the power ratings which is essential in wave energy generation applications. 
Table 2. Specifications of the designed converter [33].

\begin{tabular}{ll}
\hline \multicolumn{1}{c}{ Parameter } & Value \\
\hline Input voltage $\left(V_{\text {in }}\right)$ & $135 \mathrm{~V}$ to $270 \mathrm{~V}$ \\
Output voltage $\left(V_{\mathrm{o}}\right)$ & $400 \mathrm{~V}$ \\
Output Power $\left(P_{\mathrm{o}}\right)$ & $10 \mathrm{~kW}$ \\
DC bus voltage $\left(V_{\text {bus }}\right)$ & $600 \mathrm{~V}$ \\
Switching frequency $\left(f_{\mathrm{s}}\right)$ & $100 \mathrm{kHz}$ \\
\hline
\end{tabular}

\section{Simulation Results}

\subsection{Steady-State Conditions}

The steady-state performance of the converter outlined in Section 3 was verified by using PSIM simulations. The following five cases were considered to validate theoretical results [24]. Case 1: $V_{\text {in }}(\min )=135 \mathrm{~V}$, full load; Case 2: $V_{\text {in }}(\max )=270 \mathrm{~V}$, full load; Case 3: $V_{\text {in }}(\min )=135 \mathrm{~V}$, half load; Case 4: $V_{\text {in }}(\max )=270 \mathrm{~V}$, half load; Case $5: V_{\text {in }}(\min )=135 \mathrm{~V}, 20 \%$ of full load. Sample waveforms from PSIM simulations for Cases 1, 2, and 5 are presented in Figures 4-15. In simulations, three-phase transformers were obtained by using three single-phase transformers. Leakage and magnetizing inductances were obtained by recalculating the per-unit values of the measured values of the three-phase boost transformer in from Reference [25] (rated at $618 \mathrm{~W}$ ) built in the laboratory. These values are: total leakage inductance of $3.0 \mu \mathrm{H}$ (referred to primary side) and magnetizing inductance of $170 \mu \mathrm{H}$ (referred to primary side). The estimated leakage inductance of the boost transformer $L_{\mathrm{bl}} @ 3.0 \mu \mathrm{H}$ was slightly greater than the calculated value of the per-phase inductance required in the primary windings of the three-phase boost transformer $\left(L_{\mathrm{bt}}=2.75 \mu \mathrm{H}\right)$. Hence, no additional inductance was necessary. Thus, leakage inductance was profitably utilized to achieve ZVS. To compensate for the voltage drop due to leakage inductance (i.e., voltage drop due to commutation overlap), the turns ratio of the boost transformer was made 2.428:1 instead of 2.5806:1. For the three-phase main transformers, three ideal single-phase transformers were used as the leakage inductances were absorbed in the resonant inductances. In the simulations, the Y-connected parallel inductor $L_{\mathrm{p}}^{\prime}$, on the secondary side of three-phase main transformers $T_{1}$ and $T_{2}$ of Figure 2, was connected in $\Delta$ by taking their equivalent values (i.e., $L_{\mathrm{ab}}=L_{\mathrm{bc}} L_{\mathrm{ca}}=3 L_{\mathrm{p}}^{\prime}$ ). For MOSFET, an $R_{\mathrm{DS}}=76 \mathrm{~m} \Omega$ was used. Snubber capacitors used include the MOSFET drain to source capacitances. All remaining components were chosen as ideal. Since this resonant power converter operates in soft-switching, the effect of electromagnetic interference (EMI) was minimized. Wiring inductance at the output of inverter is used profitably as part of resonant circuit. However, to minimize the EMI and effect of other parasitic elements (due to wiring and coupling, etc.) that might still occur, techniques used in Reference [37] could be used while designing the printed circuit boards. The effect of any other parasitic elements can be minimized by using a careful design of the printed circuit board. The impact of the geometrical parameters of the PCB structure on the electromagnetic coupling is analyzed in Reference [37]. In simulations, each three-phase inverter bridge module was given with three-phase $180^{\circ}$ wide normal gating signals. To regulate output voltage, the gating signals of Module 2 were phase-shifted from those of Module 1 to give a pulse width of $\delta$. Since the calculated value of $\delta$ was very close to the value of $\delta$ to be set in the simulations, very few iterations were used in the simulations to determine the required value of $\delta$ to obtain the rated output voltage. This is an advantage as it reduces simulation time. It was observed from the simulation results [24] that all the switches, in both Module 1 and 2 of the converter, operate with ZVS for all input-voltage variation from $V_{\text {in }}(\min )$ to $V_{\text {in }}(\max )$, and for load variation from full load to $20 \%$ of full load, e.g., Figures 6, 10, and 14 . The maximum resonant current (phase) declined from approximately (i) Module 1: $13.81 \mathrm{~A}$ at $V_{\text {in }}(\max )=270 \mathrm{~V}$, full load (Figure 8a) to $2.77 \mathrm{~A}$ at $V_{\text {in }}(\min )=135 \mathrm{~V}, 20 \%$ of full load (Figure 12a); (ii) Module 2: $13.86 \mathrm{~A}$ at $V_{\text {in }}(\max )=270 \mathrm{~V}$, full load (Figure $8 \mathrm{~b}$ ) to $2.83 \mathrm{~A}$ at $V_{\text {in }}(\mathrm{min})=135 \mathrm{~V}, 20 \%$ of full load (Figure 12b). For Module 1: peak switch current with $V_{\text {in }}(\min )=135 \mathrm{~V}$ approximately decreased from $49.51 \mathrm{~A}$ at full load (Figure 6a) to $13.66 \mathrm{~A}$ 
at $20 \%$ of full load (Figure 14a). For Module 2: peak switch current with $V_{\text {in }}(\mathrm{min})=135 \mathrm{~V}$ decreased approximately from $49.45 \mathrm{~A}$ at full load (Figure $6 \mathrm{~b}$ ) to $12.13 \mathrm{~A}$ at $20 \%$ of full load (Figure $14 \mathrm{~b}$ ). It is worth noting that the peak values of the switch/resonant currents reduce as load current is reduced. The summary of power-loss breakdown analysis of the converter is presented in Table 3. A bar chart of the efficiency percentage obtained from calculations and simulations is shown in Figure 16. Comparison of the results obtained from calculations and simulations is presented in Table 4. It is to be noted that, comparing the results presented in Table 4 and in Figure $16, R_{D S}=76 \mathrm{~m} \Omega$ was chosen in the simulation for MOSFETs, and all other elements were ideal. Hence, efficiency values from simulations are higher than those from calculations.

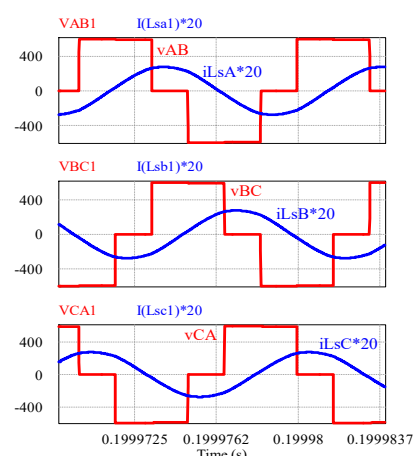

(a)

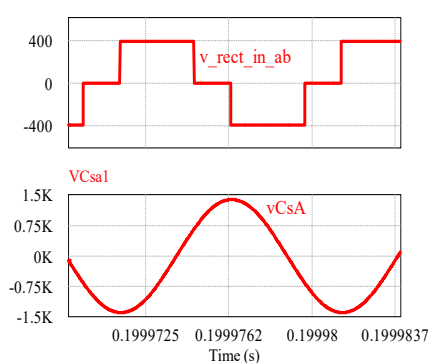

(c)

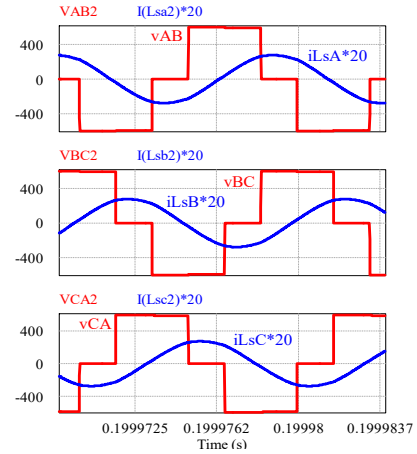

(b)

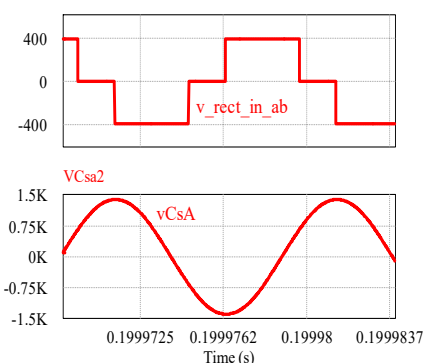

(d)

Figure 4. PSIM simulation waveforms for Case 1: $V_{\text {in }}(\min )=135 \mathrm{~V}$, full load, $R_{\mathrm{L}}=16 \Omega, \delta=180^{\circ}$. $v_{\mathrm{AB}}, v_{\mathrm{BC}}, v_{\mathrm{CA}}$, and $i_{\mathrm{LsA}}, i_{\mathrm{LsB}}, i_{\mathrm{LsC}}$ for (a) Module 1 and (b) Module 2. $v_{\text {rect_in_ab }}$ or $v_{\mathrm{Lab}}$, and $v_{\mathrm{CsA}}$ for (c) Module 1 and (d) Module 2.

\subsection{Performance Under Step Changes in Load}

A converter is robust when it maintains output voltage as constant even when the load suddenly changes. This ability of the converter is tested by simulating its performance in PSIM software for sudden variations in load. The change in load from full load to half load, and then to $20 \%$ of full load (also in reverse order), was created by operating a load control switch. The phase-shifted gating signals with appropriate phase-shift angle $\delta$, as given in Table 4, for corresponding step changes in load were applied to the MOSFETs of Module 2. Some important sample waveforms, obtained through simulations for step changes in load current from full load to half load at $t=0.2$ seconds, and half load to $20 \%$ of full load at $t=0.25$ seconds (step change is made after steady-state operation), are presented in Figure 17. The robustness of the converter is rigorously tested by creating two step changes i.e., from $20 \%$ of full load to half load at $t=0.2$ seconds, and from half load to full load at $t=0.25$ seconds. as indicated in Figure 18. It is observed from Figures 17 and 18 that there is smooth transition of output voltage during load step change while maintaining constant output voltage at the full-load value. From Figure 19, it can be seen that the resonant tank current remains sinusoidal throughout loading conditions. The variations of resonant tank currents while the load is changed from light load to higher loads are shown in Figure 20. It is observed in Figure 21 that the current through the switches did not spike up during sudden changes in loading conditions. It can also be observed from Figure 21 that all 
switches in both modules remained in ZVS, i.e., the antiparallel diodes conduct before the respective switches conduct. This can be ensured by observing negative switch currents, as shown in Figure 21.

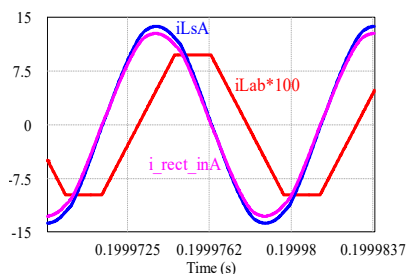

(a)
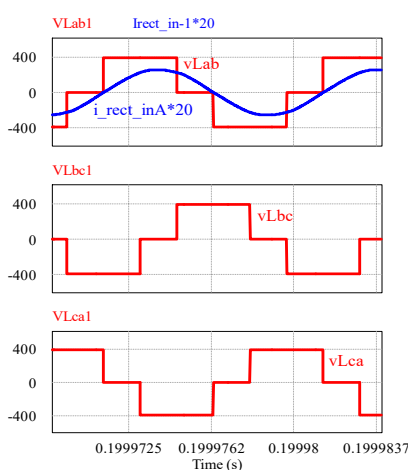

(c)

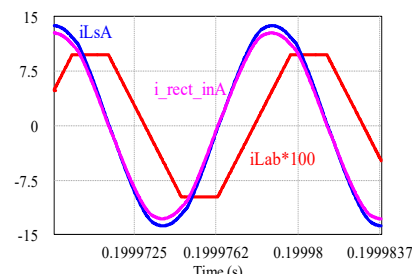

(b)
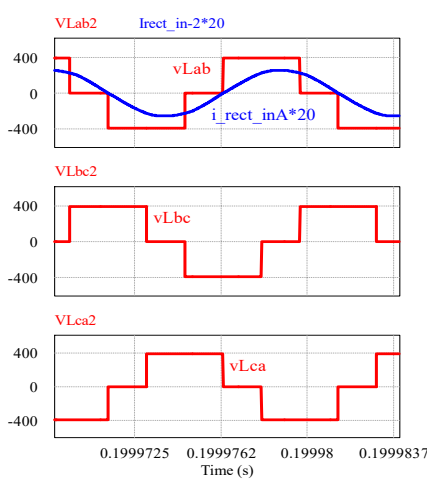

(d)

Figure 5. PSIM simulation waveforms for Case 1: $V_{\text {in }}(\min )=135 \mathrm{~V}$, full load, $R_{\mathrm{L}}=16 \Omega, \delta=180^{\circ} . i_{\mathrm{Lab}}$, $i_{\text {LsA, }}$ and $i_{\text {rect_in.a }}$ for (a) Module 1 and (b) Module 2. $v_{\text {Lab }}, v_{\text {Lbc }}, v_{\text {Lca }}$, and $i_{\text {rect_in,a }}$ for (c) Module 1 and (d) Module 2.
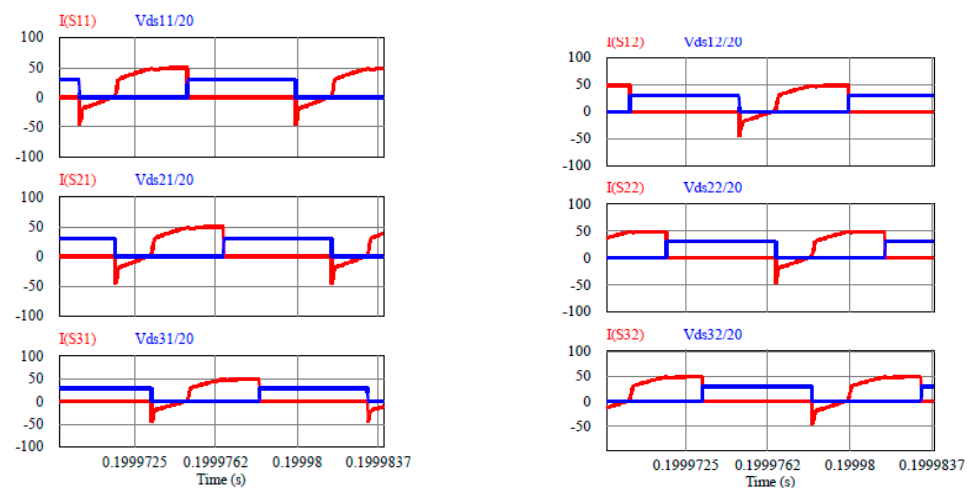

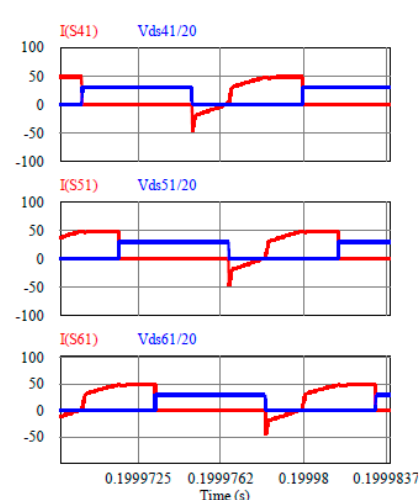

(a)

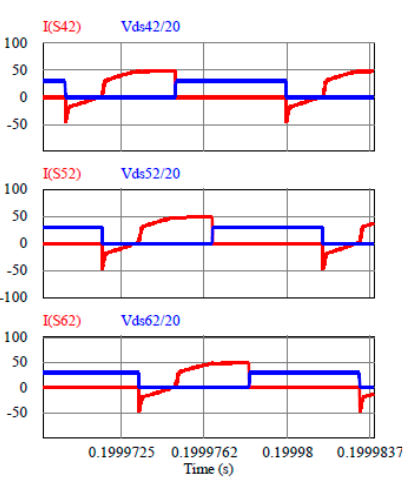

(b)

Figure 6. PSIM simulation waveforms for Case 1: $V_{\text {in }}(\min )=135 \mathrm{~V}$, full load, $R_{\mathrm{L}}=16 \Omega, \delta=180^{\circ}$. Voltage across MOSFET ( $\left.v_{\text {DS }}\right)$ and current through it $\left(i_{\mathrm{S}}\right)$ to show ZVS of switches $S_{1}-S_{3}$ and switches $S_{4}-S_{6}$ for (a) Module 1 and (b) Module 2. 


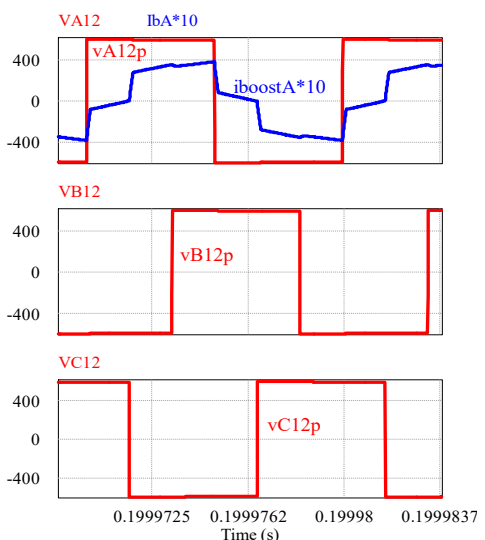

(a)

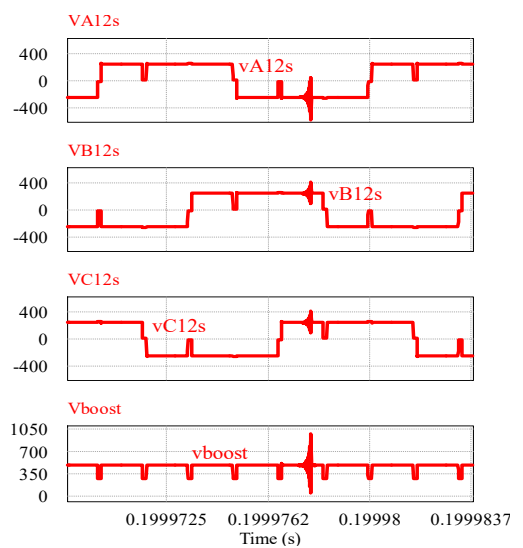

(b)

Figure 7. PSIM simulation waveforms for Case $1: V_{\text {in }}(\min )=135 \mathrm{~V}$, full load, $R_{\mathrm{L}}=16 \Omega, \delta=180^{\circ}$. Phase voltages (a) across the primary terminals $\left(v_{\mathrm{A} 12 \mathrm{p}}, v_{\mathrm{B} 12 \mathrm{p}}, v_{\mathrm{C} 12 \mathrm{p}}\right)$, and the primary current in Phase A of the three-phase boost transformer $\mathrm{T}_{3} ;(\mathbf{b})$ across the secondary terminals of three-phase boost transformer $\mathrm{T}_{3}\left(v_{\mathrm{A} 12 \mathrm{~s}}, v_{\mathrm{B} 12 \mathrm{~s}}, v_{\mathrm{C} 12 \mathrm{~s}}\right)$, and output voltage of the boost rectifier before filtering $\left(v_{\text {boost }}\right)$.

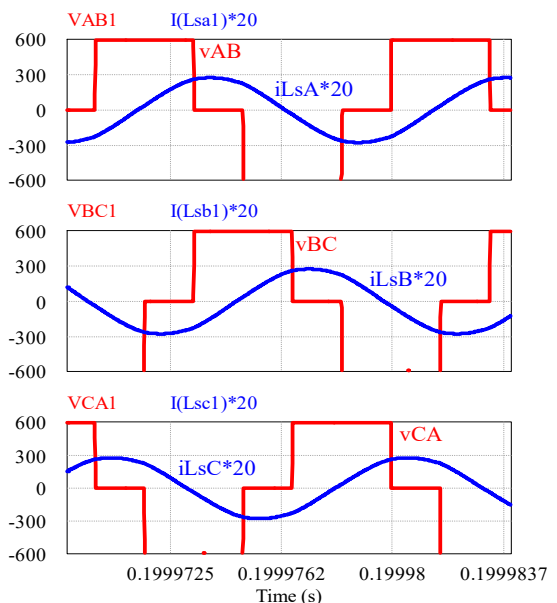

(a)

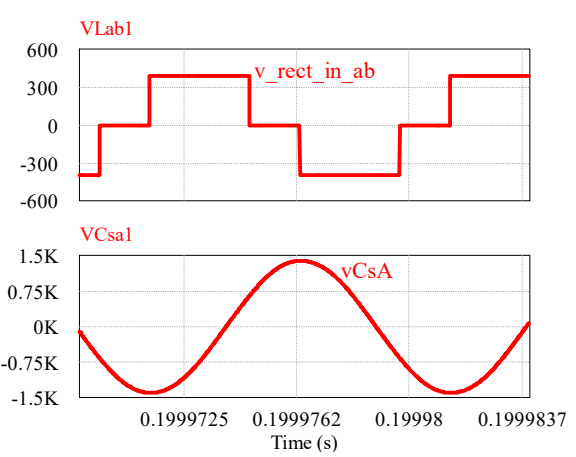

(c)

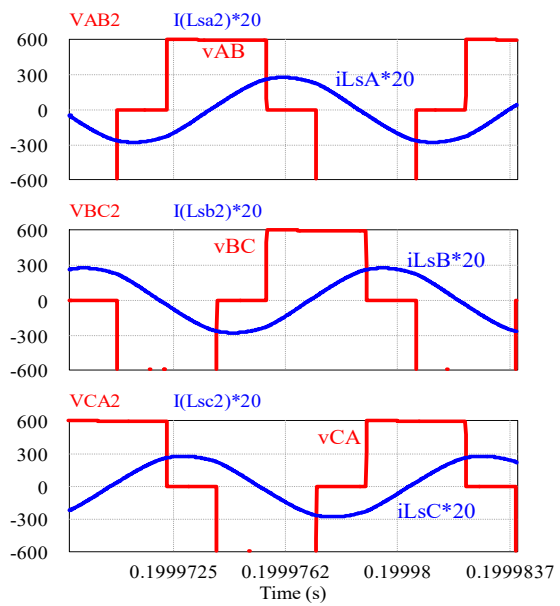

(b)

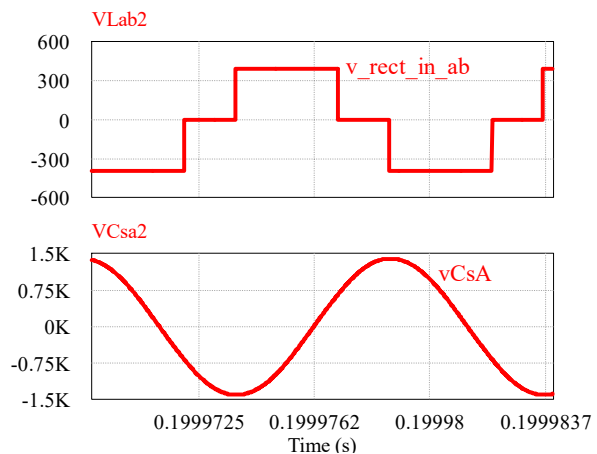

(d)

Figure 8. PSIM simulation waveforms for Case 2: $V_{\text {in }}(\max )=270 \mathrm{~V}$, full load, $R_{\mathrm{L}}=16 \Omega, \delta=84^{\circ}$. (a)-(d) Figure 4 waveforms repeated. 


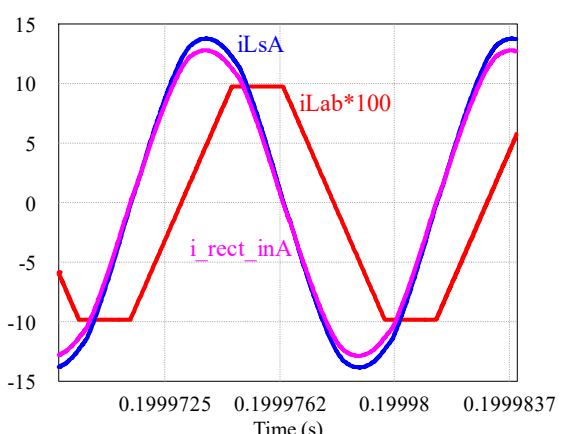

(a)

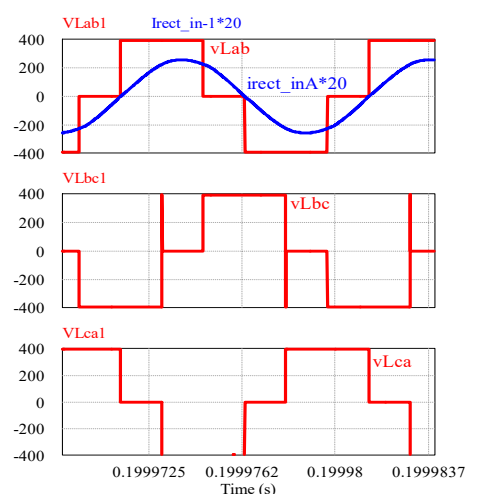

(c)

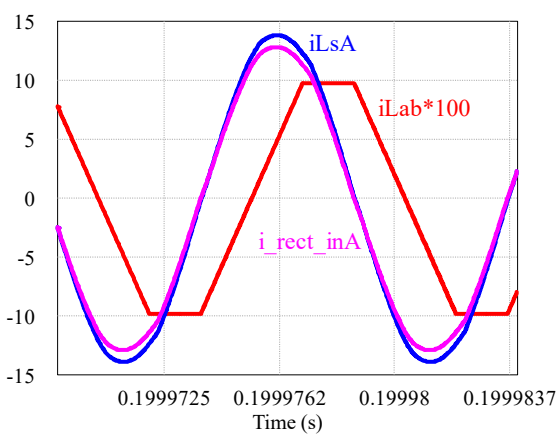

(b)

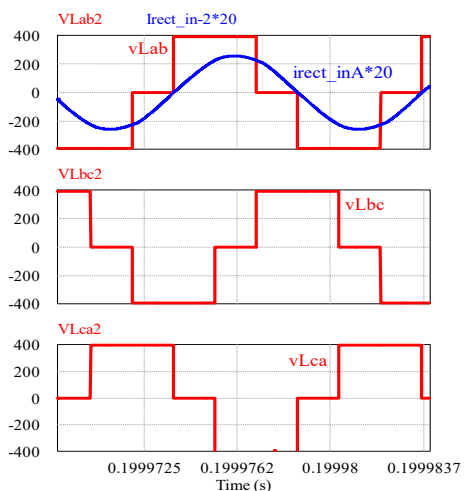

(d)

Figure 9. PSIM simulation waveforms for Case 2: $V_{\text {in }}(\max )=270 \mathrm{~V}$, full load, $R_{\mathrm{L}}=16 \Omega, \delta=84^{\circ}$. (a)-(d) Figure 5 waveforms repeated.
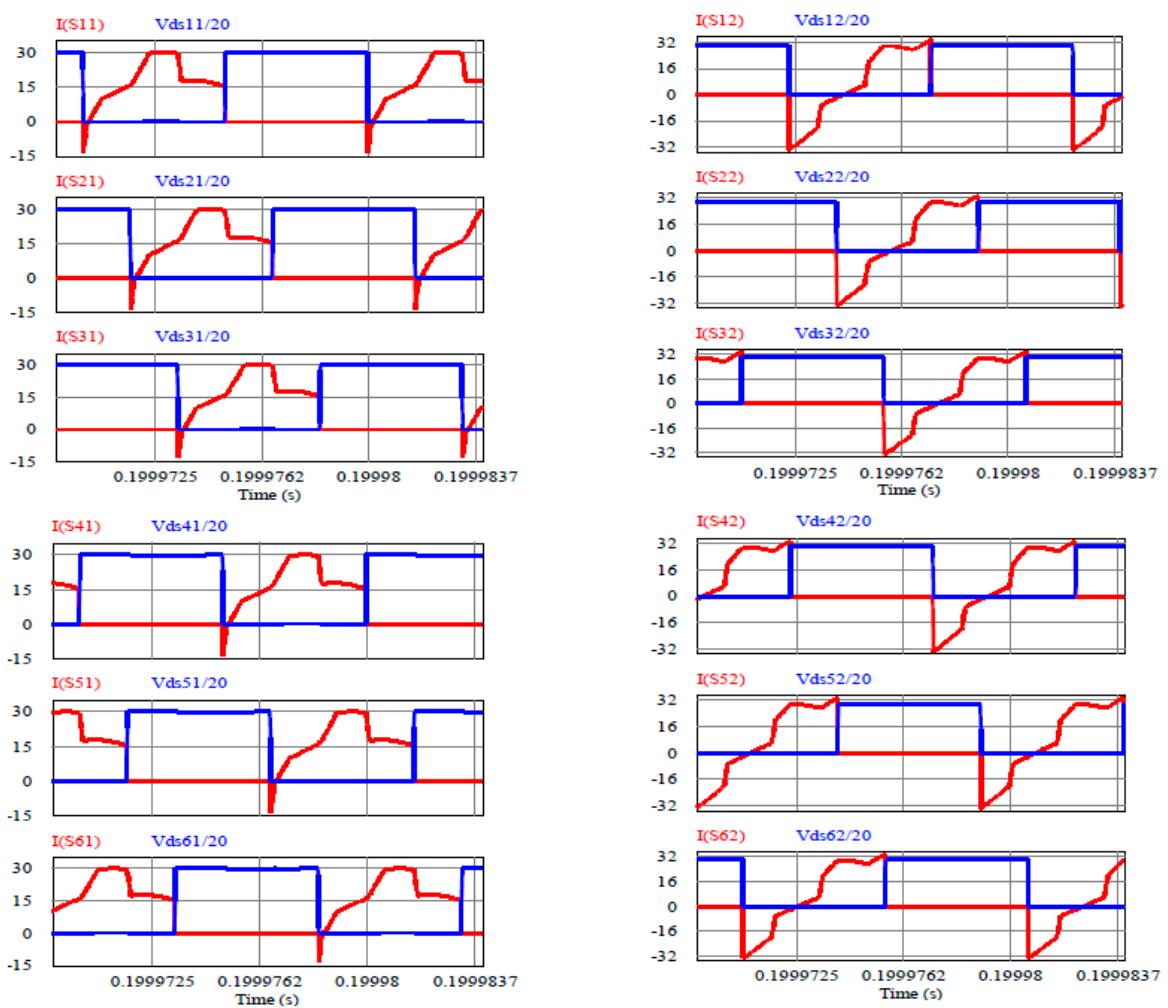

(a)

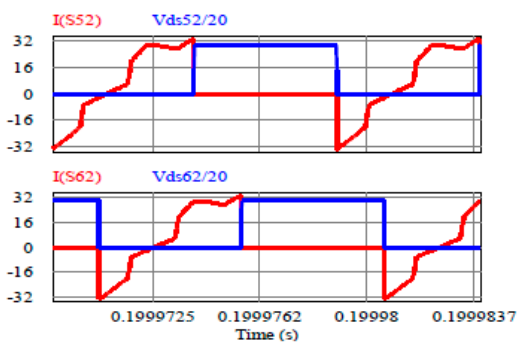

(b)

Figure 10. PSIM simulation waveforms for Case 2: $V_{\text {in }}(\max )=270 \mathrm{~V}$, full load, $R_{\mathrm{L}}=16 \Omega, \delta=84^{\circ}$. (a)-(b) Figure 6 waveforms repeated. 


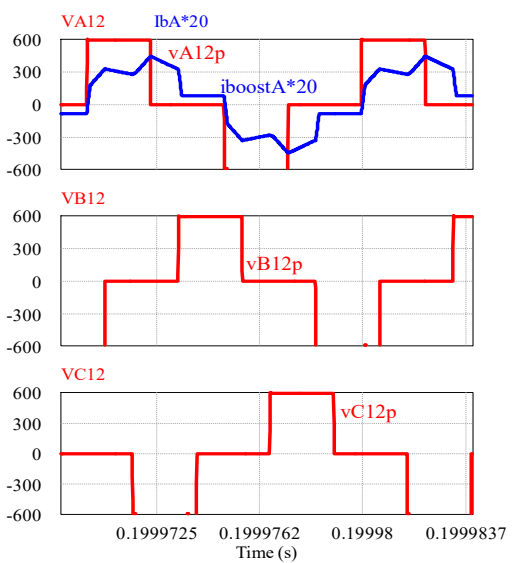

(a)

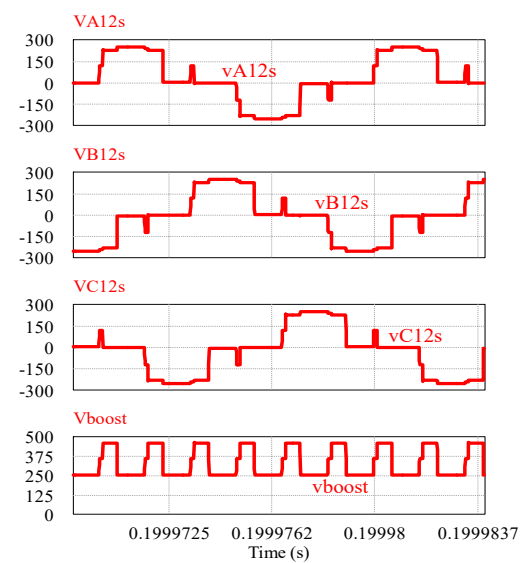

(b)

Figure 11. PSIM simulation waveforms for Case 2: $V_{\text {in }}(\max )=270 \mathrm{~V}$, full load, $R_{\mathrm{L}}=16 \Omega, \delta=84^{\circ}$. (a)-(b) Figure 7 waveforms repeated.

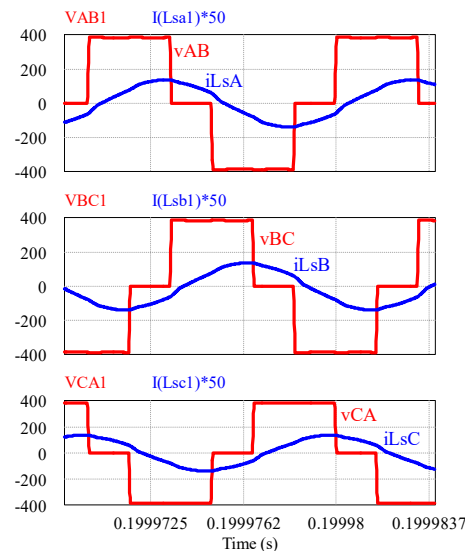

(a)

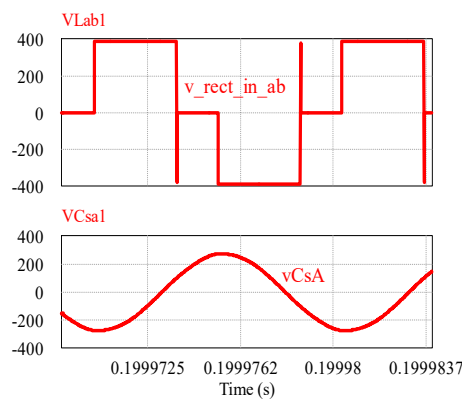

(c)

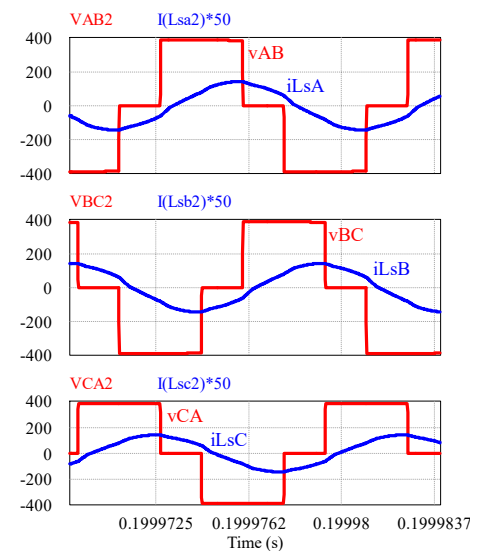

(b)

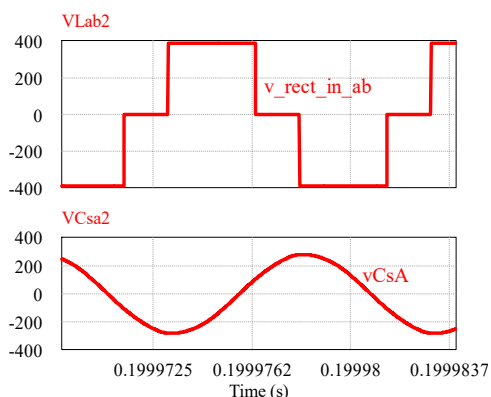

(d)

Figure 12. PSIM simulation waveforms for Case $5: V_{\text {in }}(\min )=135 \mathrm{~V}, 20 \%$ of full load, $R_{\mathrm{L}}=80 \Omega$, $\delta=98^{\circ}$. (a)-(d) Figure 4 waveforms repeated. 


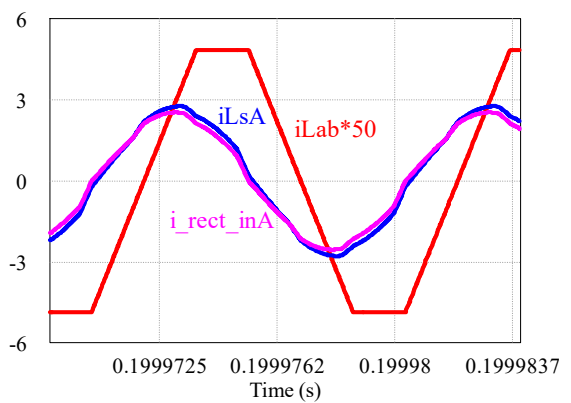

(a)

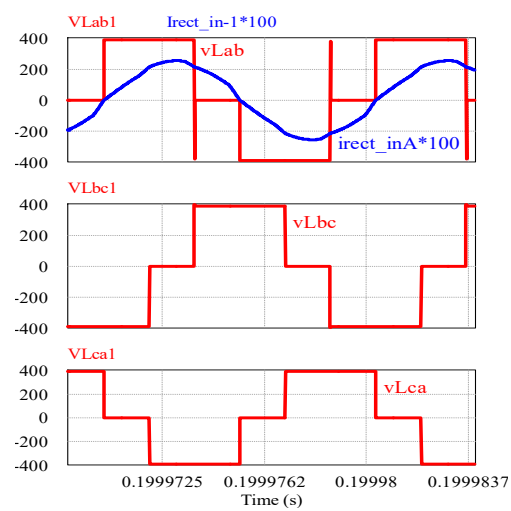

(c)

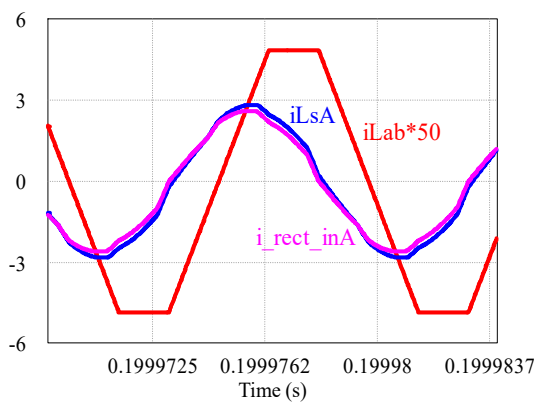

(b)

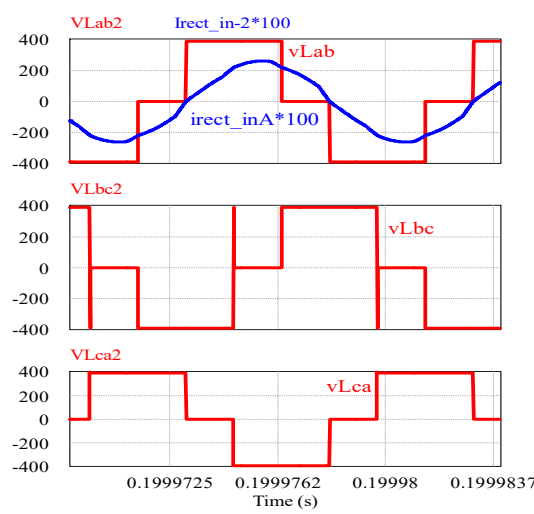

(d)

Figure 13. PSIM simulation waveforms for Case 5: $V_{\text {in }}(\min )=135 \mathrm{~V}, 20 \%$ of full load, $R_{\mathrm{L}}=80 \Omega$, $\delta=98^{\circ} .(\mathbf{a})-(\mathbf{d})$ Figure 5 waveforms repeated.
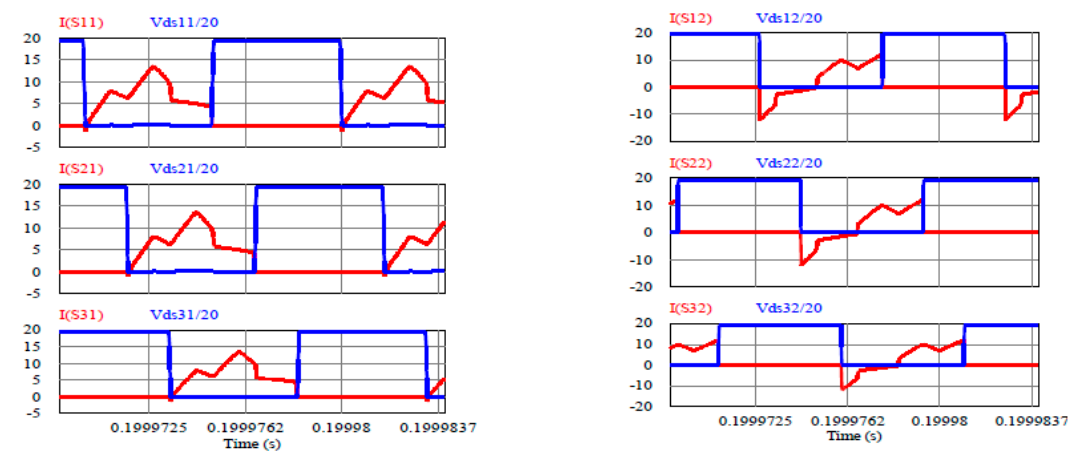

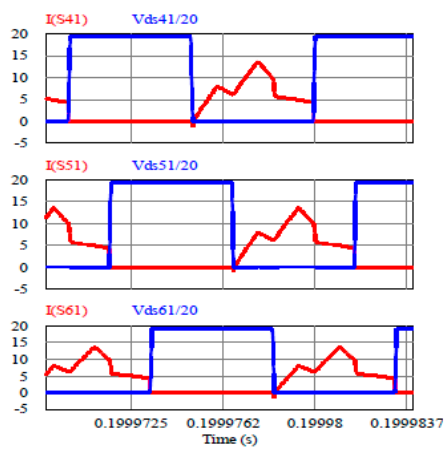

(a)

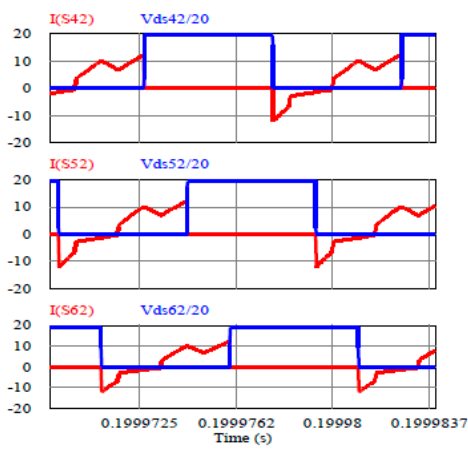

(b)

Figure 14. PSIM simulation waveforms for Case $5: V_{\text {in }}(\min )=135 \mathrm{~V}, 20 \%$ of full load, $R_{\mathrm{L}}=80 \Omega$, $\delta=98^{\circ}$. (a)-(b) Figure 6 waveforms repeated. 


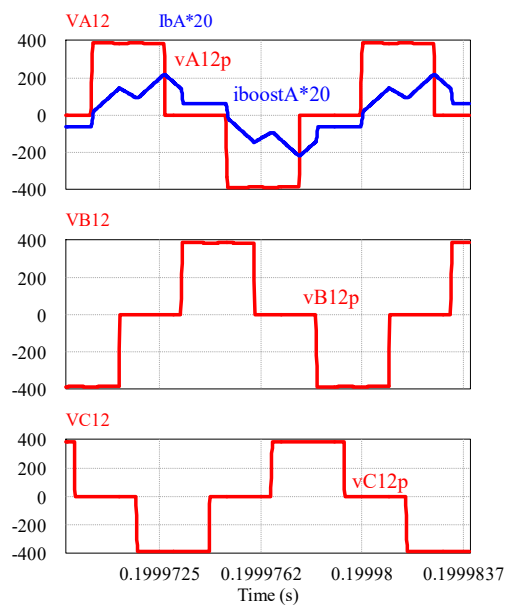

(a)

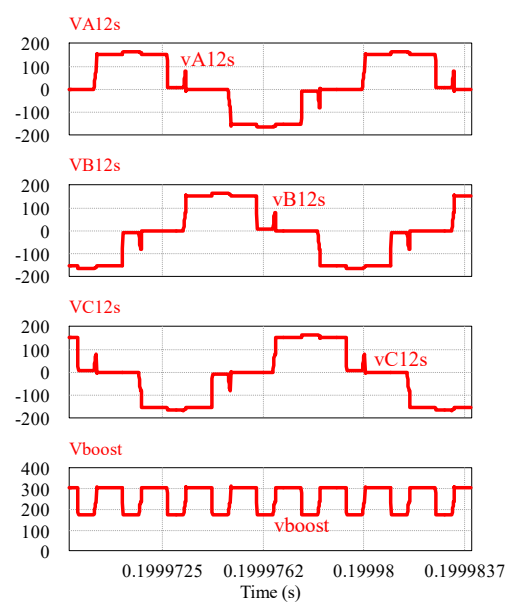

(b)

Figure 15. PSIM simulation waveforms for Case 5: $V_{\text {in }}(\min )=135 \mathrm{~V}, 20 \%$ of full load, $R_{\mathrm{L}}=80 \Omega$, $\delta=98^{\circ}$. (a)-(b) Figure 7 waveforms repeated.

Table 3. Power loss.

\begin{tabular}{|c|c|c|c|c|c|c|c|c|}
\hline \multirow{3}{*}{ Case } & \multicolumn{3}{|c|}{ Inverter (MOSFET) Losses } & \multirow{2}{*}{\multicolumn{2}{|c|}{$\begin{array}{l}\text { Rectifier Conduction } \\
\text { Losses (W) }\end{array}$}} & \multirow{3}{*}{$\begin{array}{c}\text { Transformer + } \\
\text { Q Loss (W) } \\
\text { (Assumed 1\%) }\end{array}$} & \multirow{3}{*}{$\begin{array}{l}\text { Total } \\
\text { Losses } \\
(W)\end{array}$} & \multirow{3}{*}{$\begin{array}{c}\text { Efficiency } \\
(\%)\end{array}$} \\
\hline & \multirow{2}{*}{$\begin{array}{l}\text { Turn-off } \\
\text { (W) }\end{array}$} & \multirow{2}{*}{$\begin{array}{l}\text { Conduction } \\
\text { (W) }\end{array}$} & \multirow{2}{*}{$\begin{array}{l}\text { Diode } \\
\text { (W) }\end{array}$} & & & & & \\
\hline & & & & Output & Boost & & & \\
\hline $\begin{array}{l}V_{\text {in }}=135 \mathrm{~V} \\
\text { Full load. }\end{array}$ & 334.31 & 478.81 & 10.99 & 62.50 & 99.25 & 200.00 & 1185.86 & 89.39 \\
\hline $\begin{array}{l}V_{\text {in }}=270 \mathrm{~V} \\
\text { Full load. }\end{array}$ & 136.64 & 196.47 & 10.99 & 62.50 & 49.62 & 200.00 & 656.22 & 93.84 \\
\hline $\begin{array}{l}V_{\text {in }}=135 \mathrm{~V}, \\
\text { Half load. }\end{array}$ & 70.11 & 124.10 & 0.84 & 31.25 & 49.62 & 100.00 & 375.92 & 93.00 \\
\hline $\begin{array}{l}V_{\text {in }}=270 \mathrm{~V} \\
\text { Half load. }\end{array}$ & 25.77 & 51.74 & 0.84 & 31.25 & 24.81 & 100.00 & 234.41 & 95.52 \\
\hline $\begin{array}{l}V_{\text {in }}=135 \mathrm{~V} \\
20 \% \text { load. }\end{array}$ & 9.21 & 19.66 & 1.25 & 12.50 & 19.85 & 40.00 & 102.47 & 95.12 \\
\hline
\end{tabular}

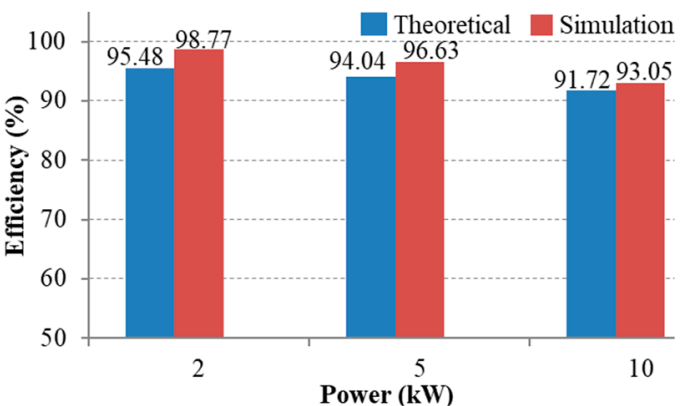

(a)

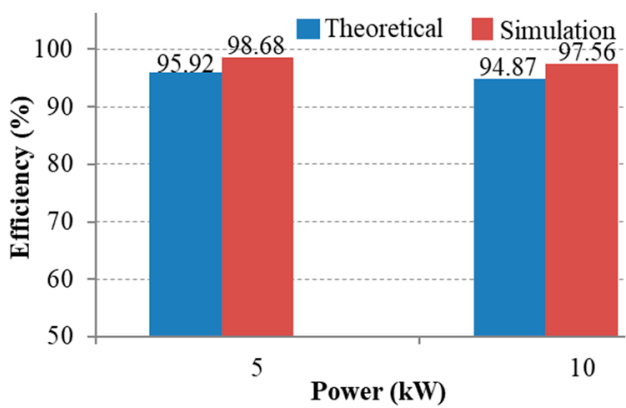

(b)

Figure 16. Theoretical and simulation efficiencies:(a) $V_{\text {in }}(\min )=135 \mathrm{~V}$ full load $(10 \mathrm{~kW})$, half load $(5 \mathrm{~kW})$, and $20 \%$ of full load; and $(\mathbf{b}) V_{\text {in }}(\max )=270 \mathrm{~V}$ full load $(10 \mathrm{~kW})$, and half load $(5 \mathrm{~kW})$. 
Table 4. Calculation and simulation results [24,33].

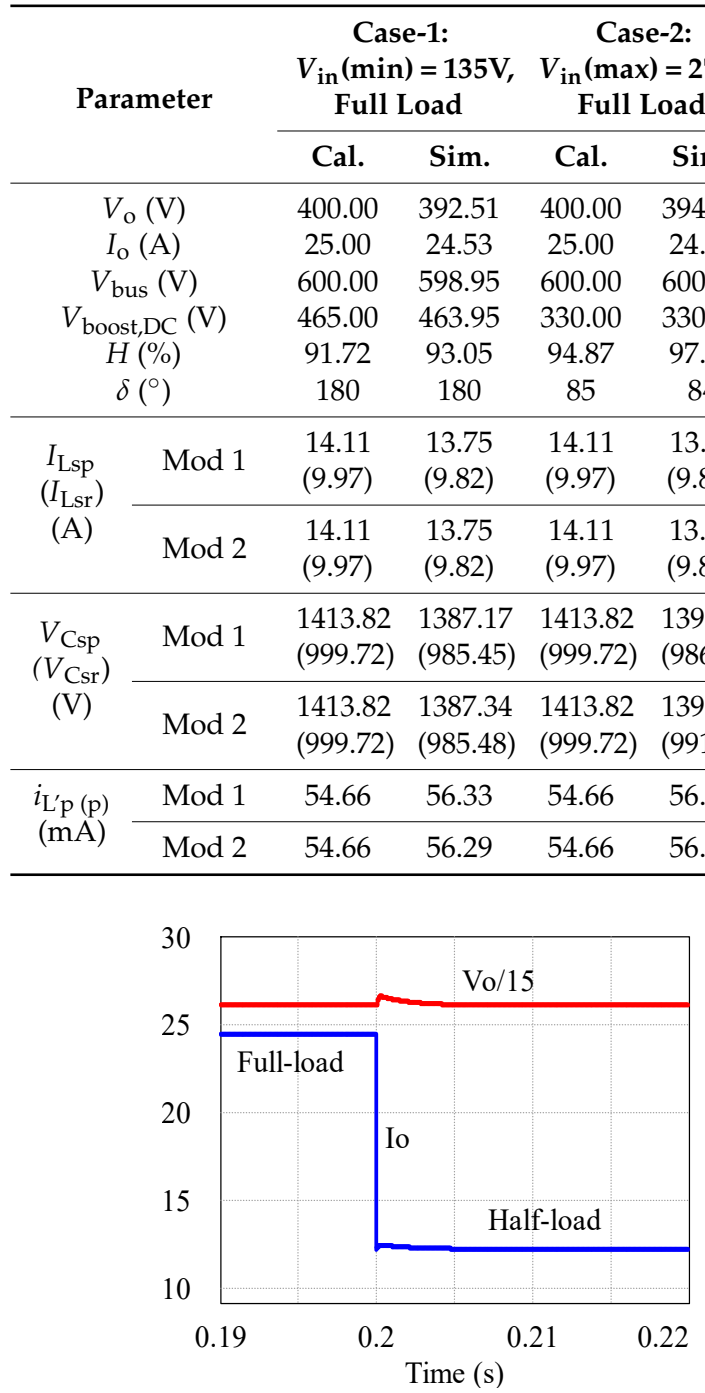

(a)

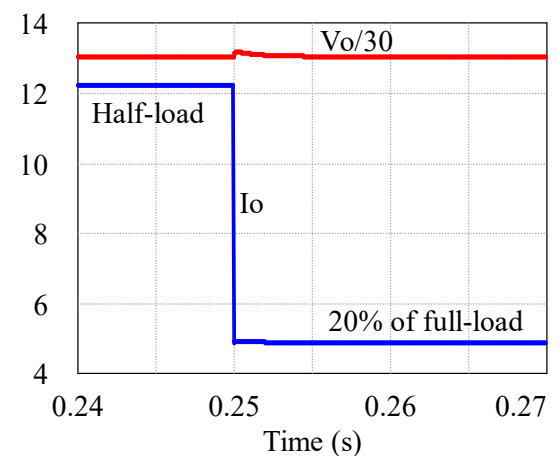

(c)

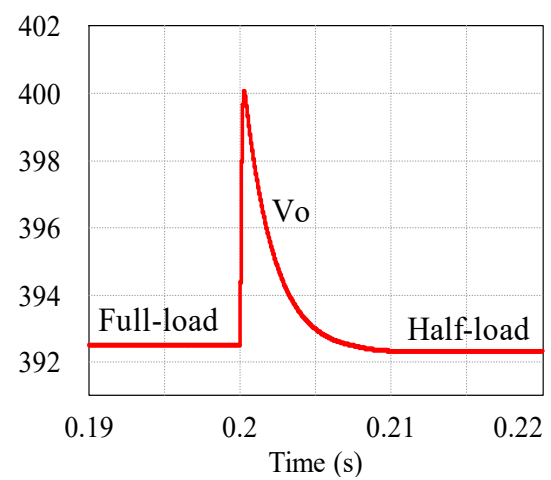

(b)

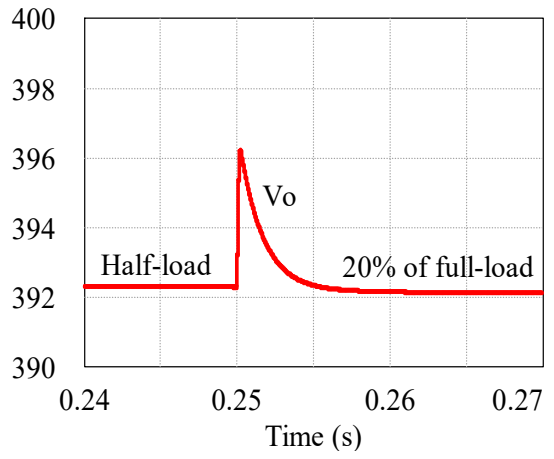

(d)

Figure 17. Simulation waveforms with $V_{\text {in }}(\mathrm{min})=135 \mathrm{~V}$ for step changes in $i_{\mathrm{o}}$ : (a) waveforms of $v_{\mathrm{o}}$ and $i_{\mathrm{O}}$, (b) expanded waveform of $v_{\mathrm{O}}$, for full load $\left(R_{\mathrm{L}}=16 \Omega, \delta=180^{\circ}\right)$ to half load $\left(R_{\mathrm{L}}=32 \Omega, \delta=107^{\circ}\right)$ at $t=0.2$ sec.; (c) waveforms of $v_{\mathrm{O}}$ and $i_{\mathrm{O}}(\mathbf{d})$ expanded waveform of $v_{\mathrm{O}}$, for half load $\left(R_{\mathrm{L}}=32 \Omega, \delta=107^{\circ}\right)$ to $20 \%$ of full load $\left(R_{\mathrm{L}}=80 \Omega, \delta=98^{\circ}\right)$ at $t=0.25 \mathrm{sec}$. Output voltage $v_{\mathrm{o}}$ to be regulated is $392 \mathrm{~V}$. 


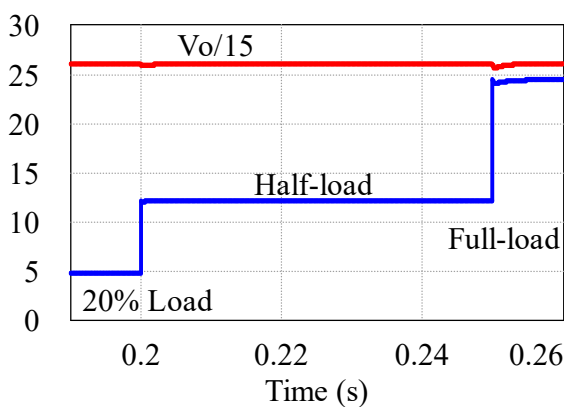

(a)

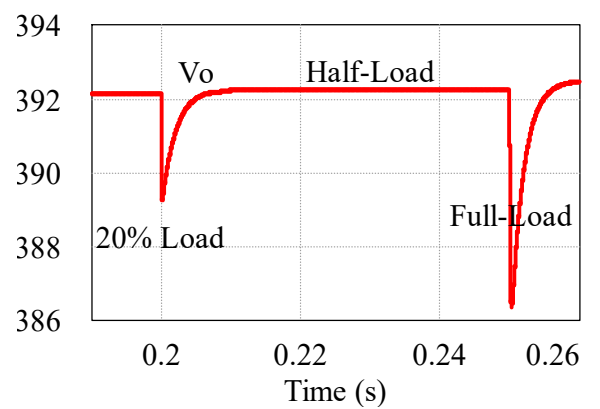

(b)

Figure 18. Simulation waveforms with $V_{\text {in }}(\min )=135 \mathrm{~V}$ for step changes in $i_{\mathrm{o}}$ from $20 \%$ of full load $\left(R_{\mathrm{L}}=80 \Omega, \delta=98^{\circ}\right)$ to half load $\left(R_{\mathrm{L}}=32 \Omega, \delta=107^{\circ}\right)$ at $t=0.2 \mathrm{~s}$, and then to full load $\left(R_{\mathrm{L}}=16 \Omega\right.$, $\left.\delta=180^{\circ}\right)$ at $t=0.25 \mathrm{~s}$ : (a) waveforms of $v_{\mathrm{o}}$ and $i_{\mathrm{o}}$, (b) expanded waveform of $v_{\mathrm{o}}$.

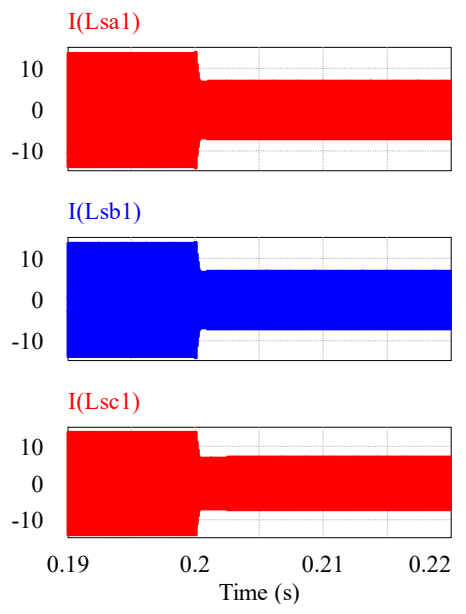

(a)

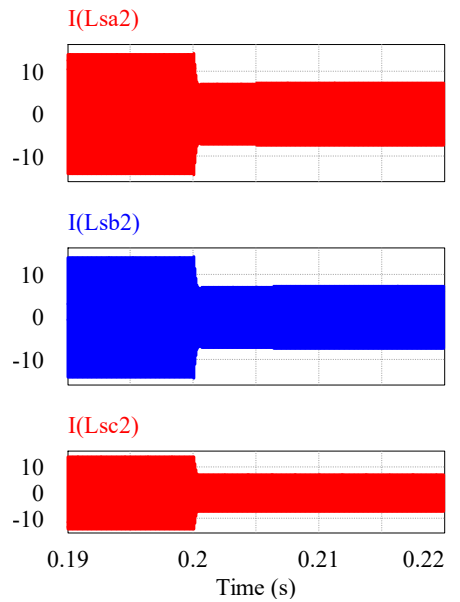

(c)

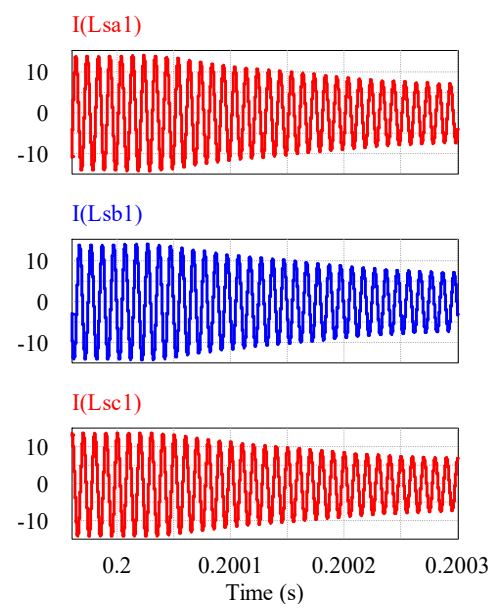

(b)

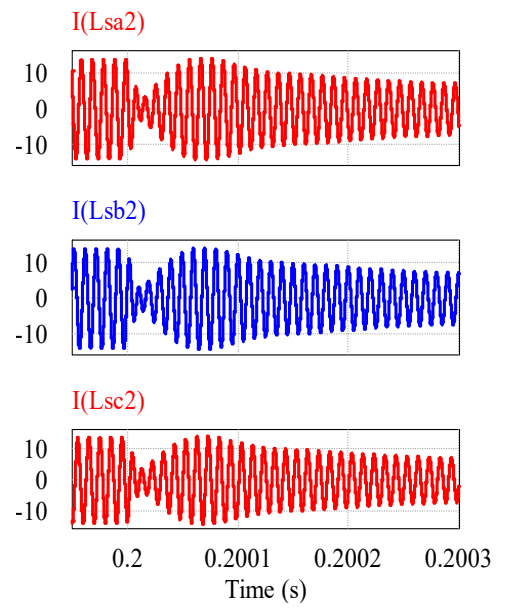

(d)

Figure 19. Simulation waveforms with $V_{\text {in }}(\mathrm{min})=135 \mathrm{~V}$ for step changes in load current at $t=0.2 \mathrm{~s}$ : (a) waveforms of resonant tank currents $\left(i_{\text {Lsa }}, i_{\text {Lsb }}, i_{\text {Lsc }}\right)$ in Phases A, B, and C, (b) expanded waveforms of $i_{\mathrm{Lsa}}, i_{\mathrm{Lsb}}, i_{\mathrm{Lsc}}$ for full load $\left(R_{\mathrm{L}}=16 \Omega, \delta=180^{\circ}\right)$ to half load $\left(R_{\mathrm{L}}=32 \Omega, \delta=107^{\circ}\right)$ for Module 1, (c) $i_{\mathrm{Lsa}}, i_{\mathrm{Lsb}}, i_{\mathrm{Lsc}}(\mathbf{d})$ expanded waveforms of $i_{\mathrm{Lsa}}, i_{\mathrm{Lsb}}, i_{\mathrm{Lsc}}$ for half load $\left(R_{\mathrm{L}}=32 \Omega, \delta=107^{\circ}\right)$ to $20 \%$ of full load $\left(R_{\mathrm{L}}=80 \Omega, \delta=98^{\circ}\right)$ for Module 2 . 


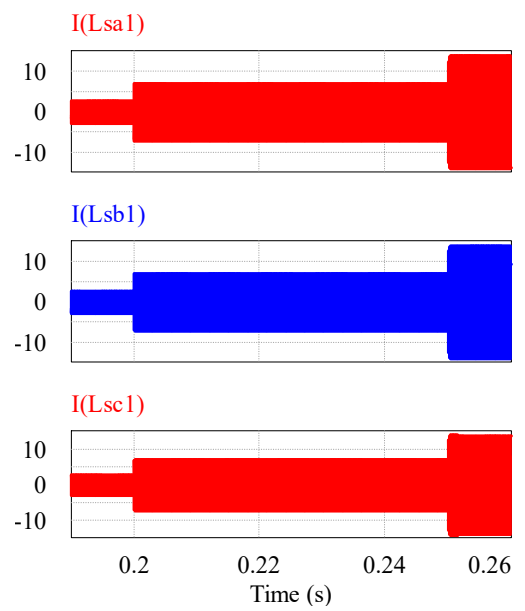

(a)

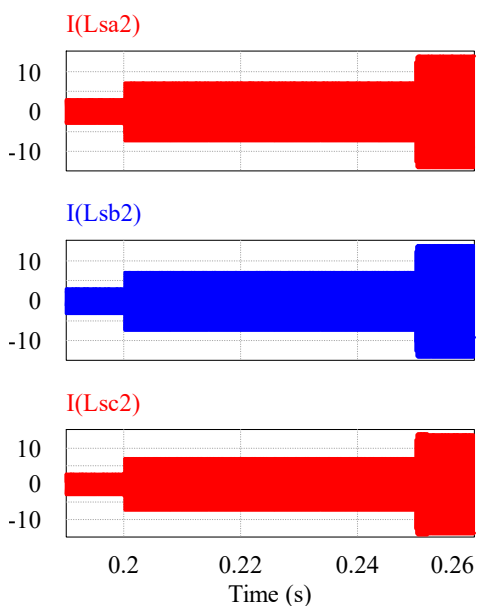

(b)

Figure 20. Simulation waveforms of resonant tank currents $\left(i_{\text {Lsa }}, i_{\text {Lsb }}, i_{\text {Lsc }}\right)$ in Phases A, B, and C with $V_{\text {in }}(\mathrm{min})=135 \mathrm{~V}$ for step changes in load current from $20 \%$ of full load $\left(R_{\mathrm{L}}=80 \Omega, \delta=98^{\circ}\right)$ to half load $\left(R_{\mathrm{L}}=32 \Omega, \delta=107^{\circ}\right)$ at $t=0.2 \mathrm{~s}$, and then to full load $\left(R_{\mathrm{L}}=16 \Omega, \delta=180^{\circ}\right)$ at $t=0.25 \mathrm{~s}$. (a) Module 1 and (b) Module 2.

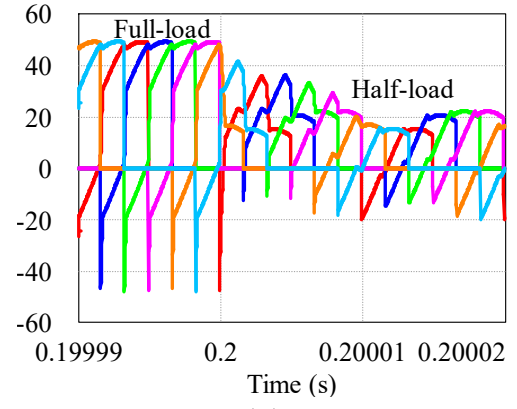

(a)

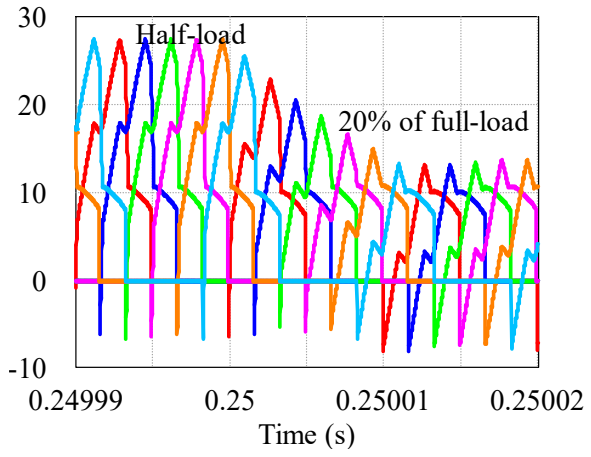

(c)

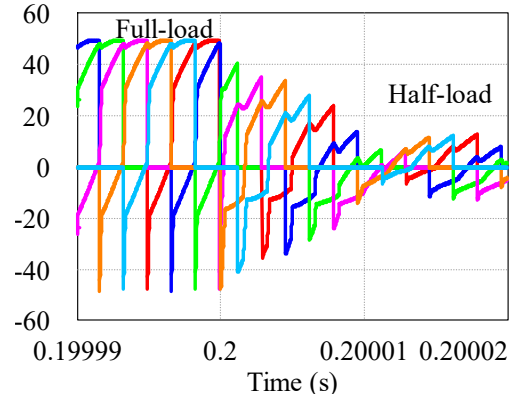

(b)

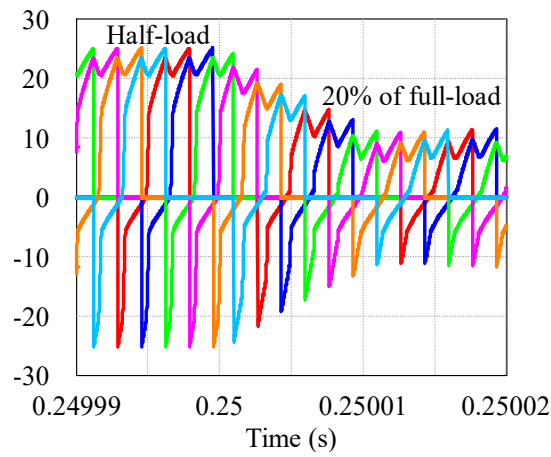

(d)

Figure 21. Simulation waveforms of switch currents $\left(i_{\mathrm{s} 1}-i_{\mathrm{s} 6}\right)$ with $V_{\mathrm{in}}(\mathrm{min})=135 \mathrm{~V}$ for step changes in load current: (a)-(b) from full load $\left(R_{\mathrm{L}}=16 \Omega, \delta=180^{\circ}\right)$ to half load $\left(R_{\mathrm{L}}=32 \Omega, \delta=107^{\circ}\right)$ at $t=0.2 \mathrm{~s}$. (a) Module 1 and (b) Module 2. (c) -(d) from half load $\left(R_{\mathrm{L}}=16 \Omega, \delta=180^{\circ}\right)$ to $20 \%$ of full load $\left(R_{\mathrm{L}}=\right.$ $80 \Omega, \delta=98^{\circ}$ ) at $t=0.25$ s. (c) Module 1 and (d) Module 2 .

\section{Conclusions}

A fixed-frequency-controlled integrated-boost dual three-phase bridge DC-DC LCL-type SRC, of 135 to $270 \mathrm{~V}$ input, $10 \mathrm{~kW}$, and $400 \mathrm{~V}$ output was designed. The performance of the designed converter has been verified by using PSIM simulations for variations in input voltage and the load. Power-loss breakdown analysis of the converter was carried out and the summary is presented. Theoretical and simulation results were compared and they agreed very closely. The designed 
converter maintained ZVS for all switches and for wide variations in supply voltage and load. This resulted in higher efficiency by minimizing turn-on losses. This feature is very useful in alternate-energy applications generating large amounts of power. Due to the advent of $\mathrm{SiC}$ power MOSFETS, e.g., Reference [38], the proposed converter could be designed for still-higher power ratings, with high switching frequency, as new MOSFETs of higher voltage ratings (>1000 V) and higher current ratings ( $>100 \mathrm{~A}$ ) are now available. IGBTs are also considered for higher power, but at the cost of reduced switching frequency. The series and parallel combinations of such three-phase cells can also be used to realize much higher power ratings. A low-power $(600 \mathrm{~W})$ prototype of the proposed converter with different input/output voltages was built in the laboratory and reported in Reference [25]. As future work, an experimental $10 \mathrm{~kW}$ converter, based on the given specifications, will be built in the power-electronics laboratory, and results will be verified with the theoretical and simulation results obtained in this paper. The effect of various parasitic elements was also included in the simulation.

Author Contributions: Investigation, N.H.; supervision, A.K.S.B.

Funding: This work was supported by a discovery grant from the Natural Sciences and Engineering Research Council (NSERC) of Canada.

Conflicts of Interest: The authors declare no conflict of interest.

\section{Appendix A. Design Equations (A24) and (A25)}

The phasor circuit used in the analysis of the Figure 3 converter is shown in Figure A1. Some of the important equations used in the converter design are given below:

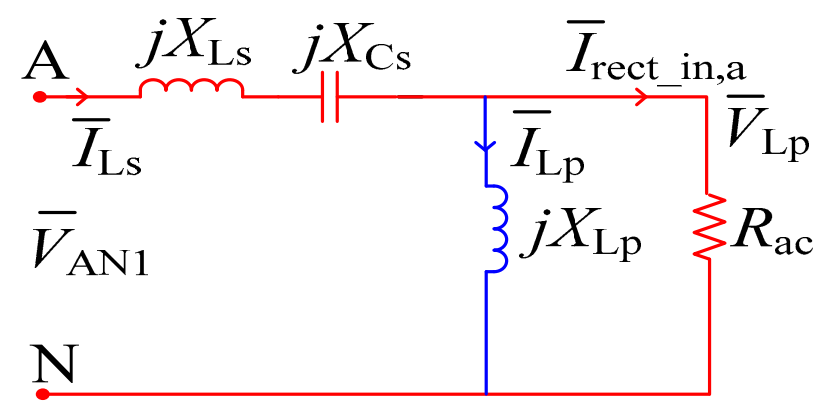

Figure A1. Phasor equivalent circuit used for analyzing Module 1 of the converter shown in Figure 3 [24,25].

RMS current through each switch is

$$
I_{\mathrm{SW}}(\mathrm{rms})=\sqrt{\frac{1}{2 \pi}\left\{I_{b}^{2}\left(\pi-\frac{\pi}{3}\right)+\frac{I_{\mathrm{Lsp}}^{2}}{2}\left(\pi-\frac{\pi}{3}+\frac{\sin 2 \Phi}{2}+\frac{\sin \left(2 \frac{\pi}{3}-2 \Phi\right)}{2}\right)+2 I_{\mathrm{b}} I_{\mathrm{Lsp}}\left(\cos \Phi+\cos \left(\frac{\pi}{3}-\Phi\right)\right)\right\}}
$$

Average current through each switch is

$$
I_{\mathrm{SW}}(\mathrm{av})=\frac{1}{2 \pi}\left\{I_{b}\left(\pi-\frac{\pi}{3}\right)+I_{L s p}\left(\cos \Phi+\cos \left(\frac{\pi}{3}-\Phi\right)\right)\right\}
$$

Average current through body diode of each MOSFET is

$$
I_{\mathrm{DM}}(\mathrm{av})=\frac{I_{L \mathrm{sp}}}{2 \pi}\left(\cos \Phi-\cos \left(\frac{\pi}{3}-\Phi\right)\right)
$$

Maximum voltage across each MOSFET is

$$
v_{\mathrm{DS}}(\max )=V_{\text {bus,max }}
$$


Average current through each diode of the boost rectifier is

$$
I_{\mathrm{Db}}=I_{\mathrm{Lf}}(\mathrm{av}) / 3
$$

Average current through inductive filter used at the output of boost rectifier is

$$
I_{\mathrm{Lf}}(\mathrm{av})=\left(I_{\mathrm{Lfmin}}+I_{\mathrm{Lfmax}}\right) / 2
$$

Maximum voltage across each of the boost rectifier diodes is

$$
V_{\mathrm{Db}}(\max )=2 V_{\text {bus }} / n_{\mathrm{b}}
$$

Average current through each diode of the output rectifier is

$$
I_{\text {Do }}(\text { ave })=I_{\mathrm{RL}}(\mathrm{av}) /(3 \times 2)
$$

Average current through the load resistance is

$$
I_{\mathrm{RL}}(\mathrm{av})=P_{\mathrm{o}} / V_{\mathrm{o}}
$$

Maximum voltage across each diode of the output rectifier is

$$
V_{\text {Do }}(\max )=V_{\mathrm{o}}
$$

Snubber capacitance used across each switch is

$$
C_{\mathrm{n}}=i_{\mathrm{o}} t_{\mathrm{f}} /\left(2 V_{\mathrm{bus}, \max }\right)
$$

Filter inductance used at the output of the boost rectifier is

$$
L_{\mathrm{f}}=V_{\mathrm{Lf}(6 \mathrm{fs})} /\left(12 f_{\mathrm{s}} \pi I_{\mathrm{Lf}(6 \mathrm{fs})}\right)
$$

Filter capacitance used at the output of the boost rectifier is

$$
C_{\mathrm{f}}=I_{\mathrm{Cf}(6 \mathrm{fs})} /\left(12 f_{\mathrm{s}} \pi V_{\mathrm{Cf}(6 \mathrm{fs})}\right)
$$

Energy stored in inductance connected in series with each phase of the primary windings of the ideal three-phase boost transformer is

$$
E_{\mathrm{Lbt}}=\frac{1}{2} L_{\mathrm{bt}} I^{2}{ }_{\mathrm{b}}>\frac{1}{2}\left(2 C_{n} V^{2}{ }_{\text {bus }}\right)
$$

Converter gain is

$$
M=\frac{1}{\left[\left\{1+\left(L_{\mathrm{s}} / L_{\mathrm{P}}\right)\left(1-\left(1 / F^{2}\right)\right)\right\}^{2}+\left\{\left(\pi^{2} / 6\right) Q(F-(1 / F))\right\}^{2}\right]^{\frac{1}{2}}}
$$

where

$$
Q=\omega_{\mathrm{r}} L_{\mathrm{s}} / R_{\mathrm{L}}^{\prime} ; F=\omega_{\mathrm{s}} / \omega_{\mathrm{r}}=f_{\mathrm{s}} / f_{\mathrm{r}} ; \omega_{\mathrm{s}}=2 \pi f_{\mathrm{s}} ; \omega_{\mathrm{r}}=2 \pi f_{\mathrm{r}}=\frac{1}{\sqrt{L_{\mathrm{s}} C_{\mathrm{s}}}}
$$

The parameters of the phasor equivalent circuit shown in Figure A1 are

$$
Z_{\mathrm{AN}}=R_{\mathrm{AN}}+j X_{\mathrm{AN}}
$$




$$
\begin{aligned}
\left|Z_{\mathrm{AN}}\right| & =\left[R^{2}{ }_{\mathrm{AN}}+X^{2}{ }_{\mathrm{AN}}\right]^{1 / 2} \\
\Phi & =\tan ^{-1}\left(\frac{X_{\mathrm{AN}}}{R_{\mathrm{AN}}}\right)
\end{aligned}
$$

where,

$$
\begin{gathered}
R_{\mathrm{AN}}=\left(\frac{R_{\mathrm{ac}} X^{2} \mathrm{Lp}}{R_{\mathrm{ac}}+X^{2}{ }_{\mathrm{Lp}}}\right) \\
X_{\mathrm{AN}}=\left[\left(X_{\mathrm{Ls}}+X_{\mathrm{Cs}}\right)+\left(\frac{R^{2}{ }_{\mathrm{ac}} X_{\mathrm{Lp}}}{R^{2}{ }_{\mathrm{ac}}+X_{\mathrm{Lp}}}\right)\right] \\
X_{\mathrm{Ls}}=\omega_{\mathrm{s}} L_{\mathrm{s}} ; X_{\mathrm{Lp}}=\omega_{\mathrm{s}} L_{\mathrm{p}} ; X_{\mathrm{Cs}}=-1 / \omega_{\mathrm{s}} C_{\mathrm{s}} \\
\left.I_{\mathrm{Lsp}}=V_{\mathrm{AN} 1} \text { (peak }\right) /\left|Z_{\mathrm{AN}}\right|
\end{gathered}
$$

Initial switch current is

$$
i_{\mathrm{Ls} 0}=I_{\mathrm{Lsp}} \sin (-\Phi)
$$

Peak resonant capacitor voltage is

$$
V_{\mathrm{Csp}}=I_{\mathrm{Lsp}}\left|X_{\mathrm{Cs}}\right|
$$

\section{References}

1. Eriksson, M.; Waters, R.; Svensson, O.; Isberg, J.; Leijon, M. Wave power absorption: Experiments in open sea and simulation. JAP 2007, 102, 1-5. [CrossRef]

2. Bostrom, C.; Leijon, M. Operation analysis of a wave energy converter under different load conditions. IET Trans. Renew. Power Gener. 2011, 5, 245-250. [CrossRef]

3. Leijon, M.; Bernhoff, H.; Agren, O.; Isberg, J.; Sundberg, J.; Berg, M.; Karlsson, K.E.; Wolfbrandt, A. Multiphysics simulation of wave energy to electric energy conversion by permanent magnet linear generators. IEEE Trans. Energy Convers. 2005, 20, 219-224. [CrossRef]

4. Kimoulakis, N.M.; Kladas, A.G.; Tegopoulos, J.A. Power generation optimization from sea waves by using a permanent magnet linear generator drive. IEEE Trans. Magn. 2008, 44, 1530-1533. [CrossRef]

5. Wang, C.; Zhang, Z. Key technologies of wave energy power generation system. In Proceedings of the IEEE Conference on Mechatronics and Automation, Takamatsu, Japan, 6-9 August 2017.

6. Vining, J.; Lipo, T.A.; Venkataramanan, G. Experimental evaluation of a doubly-fed linear generator for ocean wave energy applications. In Proceedings of the IEEE Energy Conversion Congress and Exposition, Phoenix, AZ, USA, 17-22 September 2011; pp. 4115-4122.

7. Faiz, J.; Nematsaberi, A. Linear permanent magnet generator concepts for direct-drive wave energy converters: A comprehensive review. In Proceedings of the IEEE Conference on Industrial Electronics and Applications, Siem Reap, Cambodia, 18-20 June 2017; pp. 618-623.

8. Prado, M.; Polinder, H. Direct drive in wave energy conversion-AWS full scale prototype case study. In Proceedings of the IEEE Power and Energy Society General Meeting, Detroit, MI, USA, 24-28 July 2011.

9. Gemme, D.A.; Bastien, S.P.; Sepe, R.B.; Montgomery, J.; Grilli, S.T.; Grilli, A. Experimental testing and model validation for ocean wave energy harvesting buoys. In Proceedings of the IEEE Energy Conversion Congress and Exposition, Denver, CO, USA, 15-19 September 2013.

10. Kimoulakis, N.M.; Kakosimos, P.E.; Kladas, A.G. Power Generation by using point absorber wave energy converter coupled with linear permanent magnet generator. In Proceedings of the Mediterranean Conference and Exhibition on Power Generation, Transmission, Distribution and Energy Conversion, Agia Napa, Cyprus, 7-10 November 2010.

11. Trapanese, M.; Cipriani, G.; Corpora, M.; Di Dio, V. A general comparison between various types of linear generators for wave energy conversion. In Proceedings of the IEEE OCEANS conference, Anchorage, AK, USA, 18-21 September 2017.

12. Curcic, M.; Quaicoe, J.E.; Bachmayer, R. A novel double-sided linear generator for wave energy conversion. In Proceedings of the IEEE OCEANS conference, Genova, Italy, 18-21 May 2015. 
13. Vermaak, R.; Kamper, M.J. Experimental Evaluation and Predictive Control of an Air-Cored Linear Generator for Direct-Drive Wave Energy Converters. IEEE Trans. Ind. Appl. 2012, 48, 1817-1826. [CrossRef]

14. Hodgins, N.; Keysan, O.; McDonald, A.S.; Mueller, M.A. Design and Testing of a Linear Generator for Wave-Energy Applications. IEEE Trans. Ind. Electron. 2012, 59, 2094-2103. [CrossRef]

15. Hodgins, N.; Keysan, O.; McDonald, A.; Mueller, M. Linear generator for direct drive wave energy applications. In Proceedings of the IEEE Conference on Electrical Machines, Rome, Italy, 6-8 September 2010.

16. Li, Q.; Khan, F.H.; Imtiaz, A.M. Maximum power point tracking of stirling generator and ocean wave energy conversion systems using a two-stage power converter. In Proceedings of the IEEE Workshop on Control and Modeling for Power Electronics, Salt Lake City, UT, USA, 23-26 June 2013.

17. Lu, S.Y.; Wang, L.; Lo, T.M. Integration of wind-power and wave-power generation systems using a DC micro grid. In Proceedings of the IEEE Industry Application Society Annual Meeting, Vancouver, BC, Canada, 5-9 October 2014.

18. Lafoz, M.; Blanco, M.; Ramírez, D. Grid connection for wave power farms. In Proceedings of the European Conference on Power Electronics and Applications, Birmingham, UK, 30 August-1 September 2011.

19. Garces, A.; Tedeschi, E.; Verez, G.; Molinas, M. Power collection array for improved wave farm output based on reduced matrix converters. In Proceedings of the IEEE Workshop on Control and Modelling for Power Electronics, Boulder, CO, USA, 28-30 June 2010.

20. Rhinefrank, K.; Schacher, A.; Prudell, J.; Brekken, T.K.; Stillinger, C.; Yen, J.Z.; Ernst, S.G.; von Jouanne, A.; Amon, E.; Paasch, R.; et al. Comparison of Direct-Drive Power Takeoff Systems for Ocean Wave Energy Applications. IEEE J. Ocean. Eng. 2012, 37, 35-44. [CrossRef]

21. Wu, F.; Ju, P.; Zhang, X.P.; Qin, C.; Peng, G.J.; Huang, H.; Fang, J. Modeling, Control Strategy, and Power Conditioning for Direct-Drive Wave Energy Conversion to Operate With Power Grid. Proc. IEEE 2013, 101, 925-941. [CrossRef]

22. Qing, K.; Xi, X.; Zanxiang, N.; Lipei, H.; Kai, S. Design of grid-connected directly driven wave power generation system with optimal control of output power. In Proceedings of the European Conference on Power Electronics and Applications, Lille, France, 2-6 September 2013.

23. Rao, W.F.; Zhang, B.; Pan, J.F.; Wu, X.Y.; Yuan, J.P.; Qiu, L. Voltage control strategy of DC microgrid with direct drive wave energy generator. In Proceedings of the Conference on Power Electronics Systems and Applications-Smart Mobility, Power Transfer and Security, Hong Kong, China, 12-14 December 2017.

24. Nagendrappa, H. High-Frequency Transformer Isolated Fixed Frequency DC-DC Resonant Power Converters for Alternative Energy Applications. Ph.D. Thesis, University of Victoria, Victoria, BC, Canada, July 2015.

25. Nagendrappa, H.; Bhat, A.K.S. A Fixed Frequency ZVS Integrated Boost Dual Three-Phase Bridge DC-DC LCL-Type Series Resonant Converter. IEEE Trans. Power Electron. 2018, 33, 1007-1023. [CrossRef]

26. Steigerwald, R.L.; De Doncker, R.W.; Kheraluwala, M.H. A comparison of high power DC-DC soft-switched converter topologies. IEEE Trans. Ind. Appl. 1996, 32, 1139-1145. [CrossRef]

27. Kheraluwala, M.N.; Gascoigne, R.W.; Divan, D.M.; Baumann, E.D. Performance characterization of a high-power dual active bridge DC-to-DC converter. IEEE Trans. Ind. Appl. 1992, 28, 1294-1301. [CrossRef]

28. Almardy, M.S.; Bhat, A.K.S. Three-phase LCL-type series-resonant converter with capacitive output filter. IEEE Trans. Power Electron. 2011, 26, 1172-1183. [CrossRef]

29. Steigerwald, R.L.; Roshen, W.; Saj, C.F. A high-density $1 \mathrm{~kW}$ resonant power converter with a transient boost function. IEEE Trans. Power Electron. 1993, 8, 431-438. [CrossRef]

30. Gautam, D.S.; Bhat, A.K.S. An integrated boost-dual half-bridge LCL SRC with capacitive output filter for electrolyser application. In Proceedings of the IEEE Industry Electronics Society Annual Conference, Montreal, QC, Canada, 25-28 October 2012; pp. 3376-3381.

31. Sabate, J.A.; Vlatkovic, V.; Ridley, R.B.; Lee, F.; Cho, B.H. Design considerations for high-voltage high-power full-bridge zero-voltage-switched PWM converter. In Proceedings of the Applied Power Electronics Conference, Los Angeles, CA, USA, 11-16 March 1990; pp. 275-284.

32. AGAMY, M.; Dong, D.; Garces, L.J.; Zhang, Y.; Dame, M.; Atalla, A.S.; Pan, Y. A high power medium voltage resonant dual active bridge for DC distribution networks. In Proceedings of the IEEE Energy Conversion Congress and Exposition, Milwaukee, WI, USA, 18-22 September 2016. 
33. Nagendrappa, H.; Bhat, A.K.S. A Fixed Frequency ZVS Integrated Boost Dual Three-Phase Bridge DC-DC LCL-type Series Resonant Converter for large Power Applications. In Proceedings of the IEEE International Conference on Smart Grids, Power and Advanced Control Engineering, Bangalore, India, 17-19 August 2017; pp. 99-105.

34. Yaqoob, M.; Loo, K.H.; Lai, Y.M. Fully Soft-Switched Dual-Active-Bridge Converter with Switched-Impedance- Based Power Control. IEEE Trans. Power Electron. 2018, 33, 9267-9281. [CrossRef]

35. Cao, G.; Guo, Z.; Wang, Y.; Sun, K.; Kim, H.J. A DC-DC conversion system for high power HVDC-connected photovoltaic power system. In Proceedings of the Conference on Electrical Machines and Systems, Sydney, Australia, 11-14 August 2017.

36. Suryadevara, R.; Modepalli, T.; Li, K.; Parsa, L. Three-phase current-fed soft-switching DC-DC converter. In Proceedings of the IEEE International Symposium on Industrial Electronics, Edinburgh, UK, 19-21 June 2017; pp. 899-904.

37. Bernardi, P.; Cicchetti, R.; Pelosi, G.; Reatti, A.; Selleri, S.; Tatini, M. An equivalent circuit for EMI prediction in printed circuit boards featuring a straight-to-bent microstrip line coupling. Prog. Electromagn. Res. B 2008, 5, 107-118. [CrossRef]

38. Hazra, S.; De, A.; Cheng, L.; Palmour, J.; Hull, B.A.; Allen, S.; Bhattacharya, S. High switching performance of 1700-V, 50-A SiC power MOSFET over Si IGBT/BiMOSFET for advanced power conversion applications. IEEE Trans. Power Electron. 2016, 31, 4742-4754. [CrossRef]

(C) 2019 by the authors. Licensee MDPI, Basel, Switzerland. This article is an open access article distributed under the terms and conditions of the Creative Commons Attribution (CC BY) license (http:/ / creativecommons.org/licenses/by/4.0/). 